\title{
Impact of PKC $\varepsilon$ downregulation on autophagy in glioblastoma cells
}

\author{
Ewa Toton ${ }^{1 *}$, Aleksandra Romaniuk1', Natalia Konieczna', Johann Hofmann², Jan Barciszewski ${ }^{3,4}$ \\ and Maria Rybczynska ${ }^{1}$
}

\begin{abstract}
Background: Several efforts have been focused on identification of pathways involved in malignancy, progression, and response to treatment in Glioblastoma (GB). Overexpression of PKC $\varepsilon$ was detected in histological samples from $\mathrm{GB}$, anaplastic astrocytoma, and gliosarcoma and is considered an important marker of negative disease outcome. In multiple studies on GB, autophagy has been shown as a survival mechanism during cellular stress, contributing to resistance against anti-cancer agents. The main object of this research was to determine the influence of PKC $\varepsilon$ downregulation on the expression of genes involved in autophagy pathways in glioblastoma cell lines U-138 MG and U-118 MG with high PKCE level.
\end{abstract}

Methods: We conducted siRNA-mediated knockdown of PKC $\varepsilon$ in glioblastoma cell lines and studied the effects of autophagy pathway. The expression of autophagy-related genes was analyzed using qPCR and Western blot analysis was carried out to assess protein levels. Immunostaining was used to detect functional autophagic maturation process.

Results: We found that these cell lines exhibited a high basal expression of autophagy-related genes. Our results suggest that the loss of $\mathrm{PKC} \varepsilon$ contributes to the downregulation of genes involved in autophagy pathways. Moreover, most of the changes we observed in Western blot analysis and endogenous immunofluorescence experiments confirmed dysfunction of autophagy programs. We found that knockdown of PKC $\varepsilon$ induced a decrease in the expression of Beclin1, Atg5, PI3K, whereas the expression of other autophagy-related proteins mTOR and Bcl2 was increased. Treatment of control siRNA glioma cells with rapamycin-induced autophagosome formation and increase in LC3-II level and caused a decrease in the expression of p62. Additionally, PKC siRNA caused a diminution in the Akt phosphorylation at Ser473 and in the protein level in both cell lines. Moreover, we observed reduction in the adhesion of glioblastoma cells, accompanied by the decrease in total FAK protein level and phosphorylation.

Conclusions: Effects of down-regulation of PKC $\varepsilon$ in glioma cells raised the possibility that the expression of PKC $\varepsilon$ is essential for the autophagic signal transduction pathways in these cells.

Thus, our results identify an important role of PKC $\varepsilon$ in autophagy and may, more importantly, identifyit as a novel therapeutic target.

Keywords: Autophagy, Protein kinase C epsilon, Gliomas

\footnotetext{
* Correspondence: etoton@ump.edu.pl

${ }^{1}$ Department of Clinical Chemistry and Molecular Diagnostics, Poznan

University of Medical Sciences, Przybyszewskiego 49 St., 60-355 Poznan,

Poland

Full list of author information is available at the end of the article
} 


\section{Background}

Glioblastoma (GB), WHO grade IV, is considered to be the most rapidly progressive and invasive type of primary central nervous system tumor. GB occurs more frequently than other malignant brain tumors and has a poor prognosis with a median survival of less than 1 year [1]. Even with aggressive treatment using surgery, radiation, and chemotherapy, recurrences occur in almost all cases. The main features of GBs are genomic instability, abnormal cellular proliferation, high infiltration, intensive angiogenesis, and resistance to chemotherapy [2]. Previous studies have indicated that GBs are characterized by a heterogeneous population of cells. This heterogeneity probably arose from a series of mutations. The highly unstable nature of the cells is commonly caused by mutation of tumor suppressor genes, of following proteins: p53, p21, p16, and PTEN. Several intracellular pathways have been associated with growth and survival of GB $[3,4]$.

Protein kinase $\mathrm{C}(\mathrm{PKC})$ is a multigene family of phospholipid-dependent serine-threonine kinases that are involved in numerous signal transduction cascades. Overexpression of one of the 11 known PKC isozymes, $\mathrm{PKC} \varepsilon$, is a hallmark of human glioma [5] and acts in proliferation, differentiation, adhesion, migration, gene expression, and apoptosis [6]. PKCe was found to be oncogenic in rat fibroblasts and rat colonic epithelial cells in in vitro and in vivo conditions. Rat colonic epithelial cells with overexpressed PKC $\varepsilon$ exhibited that Raf$1 /$ mitogen-activated protein kinase (MAPK) to be responsible for the PKCe-induced transformation [7]. There is increasing evidence to indicate that upregulation of $\mathrm{PKC \varepsilon}$ in GB is associated with tumor aggressiveness and is widely implicated in malignant transformation [8]. However, its role in autophagy remains unclear. Autophagy is regarded both as cell death and cell survival mechanism, which depends on the environmental conditions and cellular status.

Autophagy is a highly conserved degradation pathway whose primary task is to recycle cellular components and degrade long-lived proteins. The process of autophagy involves the formation of double-membrane autophagosomes [9]. Numerous studies have shown that in gliomas, autophagy functions mainly as a survival mechanism, stimulated through cellular damage, caused by chemotherapeutic treatment and through various metabolic stresses, such as nutrient or growth factor deprivation [10, 11]. Li et al. investigated the effect of autophagy inhibition at different stages on cytotoxicity of autophagy inducers in glioblastoma cells. Obtained data indicate that inhibition of late steps of autophagy sensitized GB cells to arsenic trioxide (ATO) treatment and induced stronger apoptosis [12]. Okhrimenko et al. found that the knockdown of PKCE selectively reduced the expression of Akt and induced cell apoptosis in the glioma cell lines and primary cultures. Moreover, overexpression of $\mathrm{PKC} \varepsilon$ protects glioma cells from the apoptosis induced by TNF-related apoptosis-inducing ligand (TRAIL) [13]. Akt (PKB) is a family of serine-threonine kinases which was first identified in 1991 independently by three different groups [14]. Akt mediates carcinogenesis and tumor progression mainly through promoting cell survival and inhibiting apoptosis in a variety of cellular systems including gliomas [15]. The survival effects of Akt are exerted by inhibiting apoptosis through phosphorylation and inactivation of several targets, including $\mathrm{Bad}$, forkhead transcription factors, c-Raf, and caspase-9 [16]. Akt also plays a critical role in cell growth by directly phosphorylating mTOR in a rapamycin-sensitive complex containing raptor $[17,18]$. The activity of Akt is regulated by phosphorylation on Thr308 by PDK-1 and on Ser473 by PDK-2 [19].

Recently, Okhrimenko et al. have shown that silencing of PKCE-induced apoptosis in glioma stem cells (GSCs), suggesting that in these cells also $\mathrm{PKC} \varepsilon$ contributes to survival and their ability to self-renew [15]. Also, the functional relationship between autophagy and apoptosis is complex, and that one can stimulate or inhibit the other [20]. These data raised the possibility that the $\mathrm{PKC} \varepsilon$ is essential for the survival of glioblastoma cells. We were trying to determine whether silencing the expression of PRKCE via RNA interference (siRNA) can affect the lifespan of cancer cells with overexpressed $\mathrm{PKC} \varepsilon$ by autophagy pathway interruption. The study also contains the assessment of the effect of different compounds (rapamycin, 3-methyladenin) on autophagy in cells with downregulated oncoprotein PKCE.

\section{Methods}

\section{Cell line and culture conditions}

The four human glioblastoma tumor cell lines such as T98-G, LN-18, U-118 MG, and U-138 MG were obtained from the American Type Culture Collection (Rockville, MD) and were grown in Eagle's Minimum Essential medium supplemented with $10 \%$ fetal bovine serum (U-138 MG, LN-18) or Dulbecco's Modified Eagle medium with $10 \%$ fetal bovine serum (U-118 MG, T98G). All glioma cell lines were kindly provided by Prof. Jan Barciszewski (NanoBioMedical Center, Adam Mickiewicz University in Poznan and Institute of Bioorganic Chemistry, Polish Academy of Sciences, Poznan, Poland). The cells' age did not exceed 15 passages.

The HeLaPKCeA/E subline was derived from parental HeLa wild-type cells, using transfection as previously described [21]. Created cell line shows constitutively active PKC $\varepsilon$ without activators such as TPA (12-O-Tetradecanoylphorbol-13-acetate). The HeLaPKCEA/E cells were grown in DMEM medium supplemented with $10 \%$ Tet- 
Approved fetal bovine serum (Clontech, Mountain View, USA), $100 \mu \mathrm{g} / \mathrm{ml}$ geneticin, and $100 \mu \mathrm{g} / \mathrm{ml}$ hygromycin (both from Roche Diagnostics, Mannheim, Germany). All cells were propagated in a humidified atmosphere containing $5 \% \mathrm{CO}_{2}$ at $37{ }^{\circ} \mathrm{C}$.

\section{siRNA transfection}

Two glioblastoma cell lines (U-138 MG and U-118 MG) were transfected with small interfering RNA against $\mathrm{PKC} \varepsilon$ (PKC $\varepsilon$ siRNA) and non-targeting siRNA (ControlsiRNA) (Santa Cruz Biotechnology, CA, USA). Transfections were performed at approximately $60 \%$ confluence in six-well plates using TransIT-siQUEST ${ }^{\circ}$ Transfection Reagent (Mirus Bio, Madison, WI, USA) according to the manufacturer's protocol. Briefly, $1 \times 10^{5}$ cells per well were seeded in complete growth medium the day before transfection. The siRNA-transfection reagent complex was prepared in a medium without FBS and incubated with cells for $72 \mathrm{~h}$ at $37{ }^{\circ} \mathrm{C}, 5 \% \mathrm{CO}_{2}$. The final concentration of the siRNA was $25 \mathrm{nM}$. In each experiment, untreated controls and mock-transfected cells were included. Cells were collected $72 \mathrm{~h}$ after transfection.

\section{Detection of PRKCE mRNA level by q-PCR}

The effect of siRNA ( $25 \mathrm{nM}$, treatment for $72 \mathrm{~h}$ ) on the expression of the PRKCE gene in two cell lines such as U-118 MG and U-138 MG was assessed using q-PCR. Briefly, total RNA was extracted with TRI Reagent (Sigma-Aldrich, St Louis, MO, USA) according to the method of Chomczynski and Sacchi [22]. RNA concentration was quantified by measuring optical density (OD) at $260 \mathrm{nM}$ using a BioPhotometer Plus (Eppendorf, Hamburg, Germany). The Transcriptor First Strand cDNA Synthesis Kit (Roche Diagnostics, IN, USA) was used to cDNA synthesis, using $0.5 \mu \mathrm{g}$ of total RNA and oligo $(\mathrm{dT})$ primer. The real-time polymerase chain reaction for $\mathrm{PKC} \varepsilon$ expression analysis was carried out using LightCycler 96 with specific primers for PRKCE gene: F-5'-TCAGCAAGGAGGCTGTCA-3', R-5' -ATGGG TGCTGCTTGATGG-3' designed with Universal Probe Library software (Roche Diagnostics, IN, USA). Amplification products of individual gene transcripts were detected via intercalation of the fluorescent dye SYBR Green (LightCycler FastStart DNA Master SYBR Green 1 kit, Roche Diagnostics, IN, USA). Cycling conditions for all amplicons were as follows: initially $95{ }^{\circ} \mathrm{C}$ for $10 \mathrm{~min}$, followed by 45 cycles at $94^{\circ} \mathrm{C}$ for $20 \mathrm{~s}, 57^{\circ} \mathrm{C}$ for $20 \mathrm{~s}$, and $72{ }^{\circ} \mathrm{C}$ for $20 \mathrm{~s}$. All cycling reactions were performed in the presence of $2.5 \mathrm{mM} \mathrm{MgCl}$. Gene-specific products were confirmed by melting curve analysis. The expression was normalized by the expression of the housekeeping gene GAPDH: F-5'-TTCGTCAT GGGTGTGAACC-3', $\quad$ R-5'-GATGATGTTCTGGA GAGCCC-3'.
qPCR array of autophagy gene expression

The effect of silencing PRKCE gene and rapamycin $(300 \mathrm{nM})$ and 3 -MA $(5 \mathrm{mM})$ treatment for $24 \mathrm{~h}$ on the expression of genes involved in the autophagy pathways was assessed using Real Time Primers ready Human Autophagy Primer Library 96 (HATPL1) (Biomol GmbH, Hamburg, Germany). The cDNA was prepared as described above. q-PCR was performed using the FastStart Essential DNA Green Master (Roche Diagnostics, IN, USA). The thermal cycle profile was $95{ }^{\circ} \mathrm{C}$ for 10 -min initial denaturation (hot start) followed by $94{ }^{\circ} \mathrm{C}$ for $20 \mathrm{~s}, 58{ }^{\circ} \mathrm{C}$ for $20 \mathrm{~s}$, and $72{ }^{\circ} \mathrm{C}$ for $20 \mathrm{~s}$ for 50 cycles. Beta-2microglobulin (B2M) expression was used as an internal control as previously described [21]. Relative quantities (RQ) of gene expression for sample comparison was calculated using the comparative threshold cycle (CT) method (also known as the $2 \Delta \Delta C T$ method). Experiments were performed in duplicates, and results show mean values normalized to the expression of indicated genes in control cells (Control siRNA-treated cells or Control cells). Results were analyzed and shown using GENE-E (Broad Institute, Cambridge, UK).

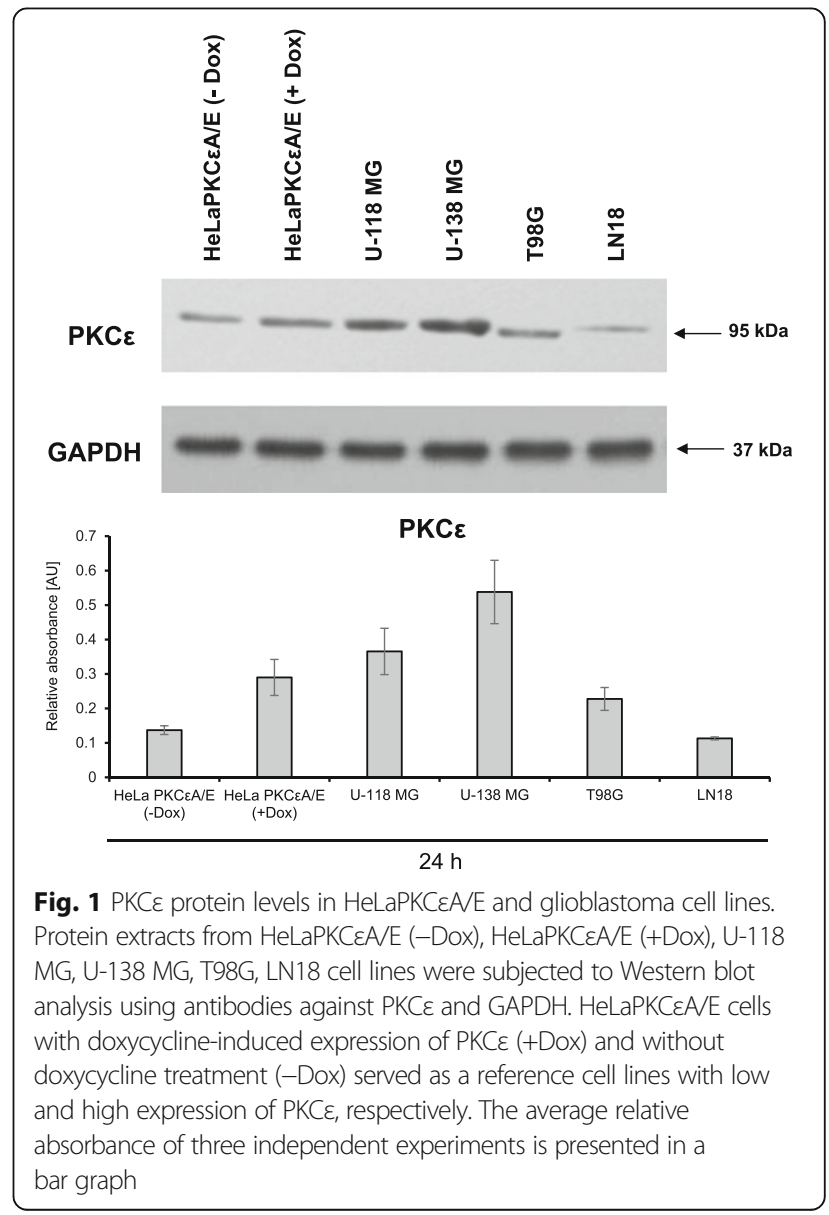




\section{Immunodetection}

U-118 MG and U-138 MG cells were treated with PKCE siRNA (25 nM) or control siRNA (25 nM) (both from Santa Cruz Biotechnology, CA, USA) for $72 \mathrm{~h}$ and rapamycin (300 $\mathrm{nM})$ or 3-methyladenine (5 mM) (both from Sigma, St Louis, MO, USA) for $24 \mathrm{~h}$. Whole cell extracts were prepared using a modified RIPA lysis buffer [21]. The protein concentration was measured using a Bradford assay (Sigma, Munich, Germany) and $30 \mu \mathrm{g}-60 \mu \mathrm{g}$ of protein extracts were separated by electrophoresis on $4-20 \%$ Mini-PROTEAN Stain-free gels (BioRad, Hercules, CA). Standard immunodetection was performed, using a PVDF membrane (Pierce Biotechnology, Rockford, USA). The following antibodies were used for detection: anti-PKCE, anti-BECN1, anti-Bcl-2, anti-FAK, anti-pFAK (Tyr-397), anti-pFAK (Tyr 576/ 577), anti-GAPDH, anti-rabbit IgG-HRP (all from Santa Cruz Biotechnology, CA, USA), antiMAPLC3 $\beta$ (Sigma, St Louis, MO, USA), anti-ATG5, anti-mTOR, anti-SQSTM1/p62, anti-Akt and antipAkt (Ser473) (from Cell Signaling Technology, Danvers, MA, USA). The 1:1000 dilution of primary antibody was used. The proteins were visualized using a SuperSignal ${ }^{\odot}$ West Pico Chemiluminescent Substrate and CL-X Posure ${ }^{\mathrm{TM}}$ film (Pierce
Biotechnology, Rockford, USA). Densitometric scanning of the blots was quantified with LabWorks software version 4.6 using a BioImaging Systems EpiChemi $^{3}$ Darkroom (UVP, Inc., Upland, CA, USA). The scan of one out of three performed experiments is shown (Figs. 1, 3, 6, 7, 8, 9, 11 and 12).

\section{Autophagosome visualization}

The study was carried out in 6-well culture dishes with glass coverslips. HeLaPKCeA/E, cells $\left(5 \times 10^{4} /\right.$ $\mathrm{ml}$ ) were incubated overnight to reach sedimentation and then were treated with $2 \mu \mathrm{g} / \mathrm{ml}$ Dox for $24 \mathrm{~h}$ and $300 \mathrm{nM}$ rapamycin for $24 \mathrm{~h}$. U-138 MG and U-118 MG cells $\left(5 \times 10^{4} / \mathrm{ml}\right)$ were incubated overnight to reach sedimentation and then were treated with PKCe siRNA (25 nM) or control siRNA (25 $\mathrm{nM}$ ) for $72 \mathrm{~h}$ and rapamycin $(300 \mathrm{nM})$ for $24 \mathrm{~h}$. For autophagosome detection, cells were stained with primary antibody rabbit anti-MAPLC3 $\beta$ (Sigma, St Louis, MO, USA, 1:200) as previously described [21]. The cultures were incubated with Alexa Fluor 488 goat anti-rabbit IgG secondary antibody fluorescent dye (Life Technologies, Molecular Probes, Grand Island, NY, USA) and recorded at $488 \mathrm{~nm}$ using a fluorescent microscope (Carl Zeiss, Gőttingen, Germany). a

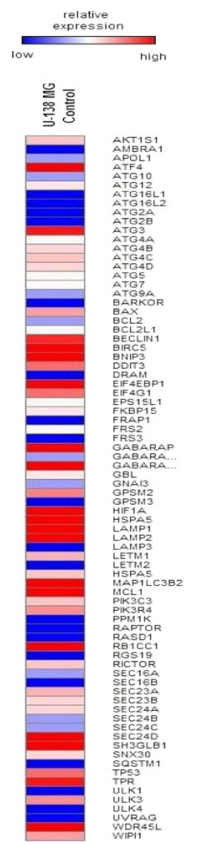

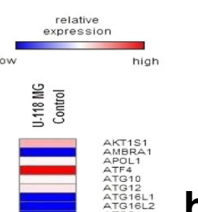

b

\begin{tabular}{|c|c|c|c|}
\hline Cell lines $\begin{array}{r}\text { The expression } \\
\text { level }\end{array}$ & $\begin{array}{c}\text { GROUP I } \\
\text { High expression }\end{array}$ & $\begin{array}{c}\text { GROUP ॥ } \\
\text { Low expression }\end{array}$ & $\begin{array}{c}\text { GROUP III } \\
\text { Moderate expression }\end{array}$ \\
\hline U-138 MG & 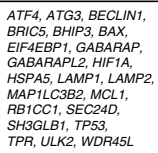 & $\begin{array}{l}\text { AMBRA1, ATG16L1, } \\
\text { ATG16L2, ATR2A, } \\
\text { ATG2B, BARCOR, BCL2, } \\
\text { DRAM, FRAPPI, FRSS3, } \\
\text { GPSM3, LAMP3, LETM2, } \\
\text { PPM1K, RAPTOR, } \\
\text { RADS1, RGS19, } \\
\text { SQSTM1, ULK1, ULK4, } \\
\text { UVRAG }\end{array}$ & $\begin{array}{l}\text { ATG12, ATG4A, ATG5, } \\
\text { ATGZ, BCLLL1, } \\
\text { EPSSLL1, FKKBP15, } \\
\text { FRS2, GBL }\end{array}$ \\
\hline U-118 MG & 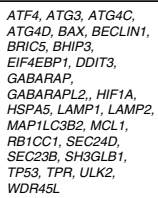 & 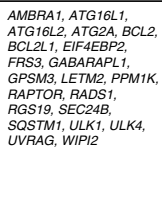 & 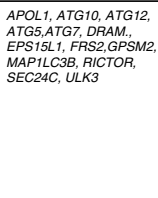 \\
\hline
\end{tabular}

Fig. 2 Basal expression of autophagy-related genes in U-138 MG and U-118 MG cell lines. a Heat maps of differentially expressed autophagy-related genes in U-138 MG and U-118 MG cell lines with high basal PKC expression levels. Each row represents a relative gene expression normalized to Beta-2-microglobulin gene (B2M) expression. Red color indicates genes with high relative expression, and blue color indicates genes with low relative expression. Results show mean values from three independent experiments performed in duplicates. b Classification of autophagy genes according to the relative expression level in U-138 MG and U-118 MG cell lines. Group I contains genes with the highest expression, Group II with the lowest, and Group III with moderate expression levels 


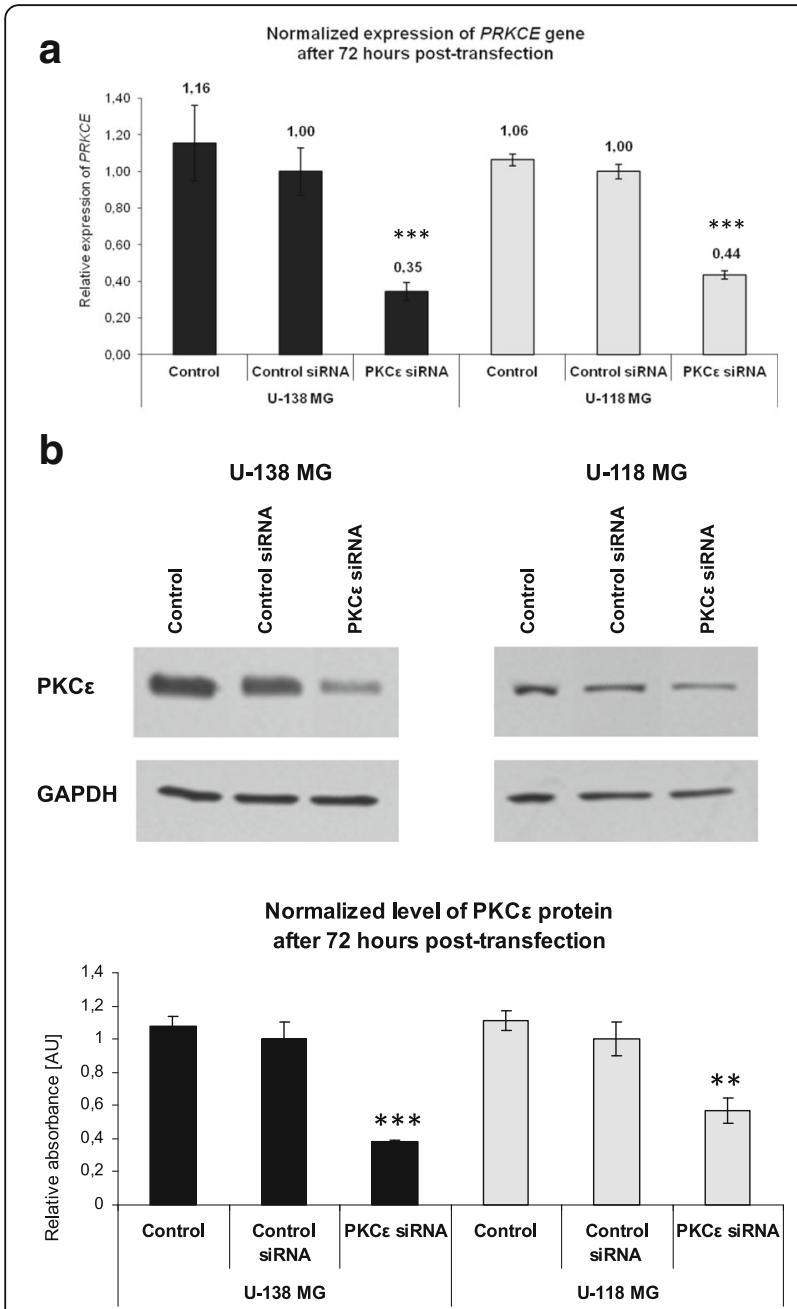

Fig. 3 The effect of PRKCE silencing on U-138 MG and U-118 MG cells. Cells were harvested $72 \mathrm{~h}$ after transfection with non-targeting siRNA (Control siRNA) or PKCE siRNA. The downregulation of PRKCE mRNA expression (a) and PKC $\varepsilon$ protein level (b) are shown. The bar graphs present average values of three independent experiments. ${ }^{* *}$ $P<0.01,{ }^{* * *} P<0.001$

\section{Attachment assay}

After transfection, cells were washed with PBS, harvested by trypsin, resuspended in fresh medium and counted. For attachment assay, cells were seeded in 6well culture plates $\left(7,5 \times 10^{4} / \mathrm{ml}\right)$ coated with Matrigel (Corning Life Sciences, NY, USA). Culture plates were prepared according to the instructions of the manufacturer. Next, the cells were incubated at $37{ }^{\circ} \mathrm{C}$. During microscopic observation, photographs were taken (Axiovert $40 \mathrm{CFL}$, Zeiss, Göttingen, Germany) after 60 and $180 \mathrm{~min}$ of incubation. A representative picture of two performed experiments is shown (Fig. 12a and b). The percentage of adhesion cells was calculated as the ratio of adhesion cells to total cells counted. We counted a minimum 100 cells per field and at least three areas in each well.

\section{Statistical analysis}

All results are means from three or five separate experiments unless specified otherwise. Statistical analysis was performed by one-way ANOVA (GraphPad Prism, San Diego, CA). $P<0.05$ was considered as significant difference.

\section{Results}

Level of PKC $\varepsilon$ in glioblastoma cell lines

Several efforts have been focused on identification of pathways involved in malignancy, progression, and response to treatment in GB [23, 24]. It has been suggested that high $\mathrm{PKC} \varepsilon$ level contributes to cancer development and increases the ability of tumor cells to metastasis [25-27]. Overexpression of PKCE was detected earlier in cancer cells from astrocytoma, GB, and gliosarcoma [5, 28]. In line with others [15, 29] we also find $\mathrm{PKC \varepsilon}$ is highly expressed in glioblastomas. In this study, we assessed the level of PKC $\varepsilon$ protein in selected glioblastoma cell lines as follows: U-118 MG, U-138 MG, T98G, and LN18 after $24 \mathrm{~h}$ of incubation. The HeLaPKCeA/E subline (with overexpressed PKCeA/E) containing a constitutively active rat $\mathrm{PKC} \varepsilon$ induced by $24 \mathrm{~h}$ treatment with $2 \mu \mathrm{g} / \mathrm{ml}$ doxycycline (Dox) served as a positive control in Western blot analysis [27]. The level of PKCE protein is varied depending on the cell line. The U-138 MG cells presented the highest level of $\mathrm{PKC} \varepsilon$ protein among studied cell lines. Two GB cell lines such as U-138 MG and U-118 MG compared to doxycycline-induced HeLaPKCeA/E cells (with overexpressed $\mathrm{PKC} \varepsilon \mathrm{A} / \mathrm{E}$ ) exhibited higher $\mathrm{PKC} \varepsilon$ protein level, whereas LN18 and T98G cell lines presented lower expression level (Fig. 1). To verify the significance of high $\mathrm{PKC} \varepsilon$ level in gliomas, we chose two cell lines for further analysis as follows: U-138 MG and U-118 MG.

\section{Assessment of autophagy gene expression in U-138 MG and U-118 MG}

$\mathrm{PKC \varepsilon}$ is potentially related to pathways that promote survival and inhibit apoptosis of cancer cells [30]. The main process involved in cell death and survival is autophagy. It plays a dual role in tumor development. On the one hand, it enables tumor cells to survive under adverse conditions. On the other hand, it limits the cell growth and genomic instability. These characteristics indicate that autophagy may represent a novel therapeutic target [31]. It has been reported that some members of PKC family (PKC $\alpha, P K C \delta$ and $\mathrm{PKC} \theta$ ) are involved in autophagy induction [32-35]. Furthermore, several studies have used pharmacological activators or inhibitors of PKCs to establish their role in autophagy. Safingol induces autophagy in 


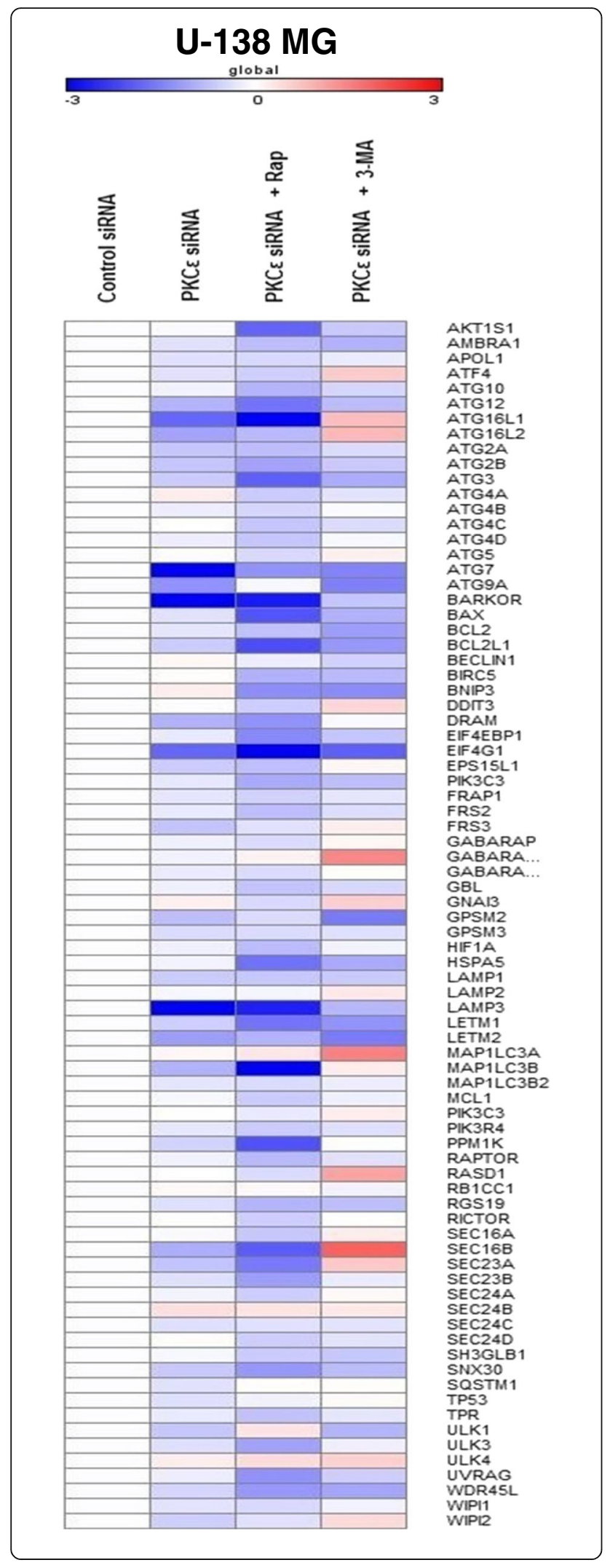

Fig. 4 Changes in autophagy gene expression in U-138 MG cells after PKC $\varepsilon$ downregulation and rapamycin or 3-MA treatment. The heat map shows the relative expression of human autophagy genes in $\mathrm{U}$ $138 \mathrm{MG}$ cells transfected for $72 \mathrm{~h}$ with PKC $\varepsilon$ siRNA (PKC $\varepsilon$ siRNA) and in cells transfected and then treated for $24 \mathrm{~h}$ with rapamycin (PKC $\varepsilon$ siRNA + Rap) or 3-MA (PKCE siRNA + 3-MA). Each row represents an average gene expression normalized to the expression of the indicated gene in cells transfected with non-targeting siRNA (Control siRNA). Red color indicates genes that were upregulated, and blue color indicates genes that were downregulated. White indicates genes whose expression is unchanged in analyzed cells as compared to Control siRNA.

Experiments were performed three times in duplicates

solid tumor cells through inhibition of PKC ( $\beta \mathrm{I}, \delta$, and $\varepsilon$ ) and PI3-kinase pathway [36].

However, since there are no reports about the connection between PKCE expression and autophagy process, we assessed the basal expression of autophagy-related genes in glioblastoma cell lines with high PKCE level (Fig. 2a). Analysis of the gene expression profile indicates high expression of autophagyrelated genes and similar transcriptional profiles in U138 MG and U-118 MG cell lines. Depending on the initial level of relative expression, we classified autophagy genes into three groups: I-genes with high expression, II-genes with low expression, III-genes with moderate expression level (Fig. 2b). We observed consistent alterations in the expression of certain genes involved in the activation of autophagy (upregulation of, e.g., BECLIN1, MAP1LC3B2) as well as genes related to autophagy inhibition (downregulation of, e.g., $B C L 2, R A P T O R$ ). Our present data suggest that high level of $\mathrm{PKC \varepsilon}$ expression may be correlated with upregulation of autophagy process (Figs. 1 and 2).

\section{Downregulation of PRKCE expression}

It was reported that glioblastoma cells have distinct transcriptional profiles depending on molecular subtype and grade $[37,38]$. The expression profile of studied glioblastoma cell lines with high $\mathrm{PKC} \varepsilon$ level suggests basal upregulation of autophagy pathways. To determine the role of $\mathrm{PKC} \varepsilon$ in the regulation of autophagy pathways in glioma cells, we used the siRNA against $\mathrm{PKC} \varepsilon$ (PKCe siRNA). We obtained about $65 \%$ and $56 \%$ decrease in mRNA (Fig. 3a) and $62 \%$ and $42 \%$ reduction in protein content for U-138 MG and U-118 MG cells, respectively (Fig. 3b).

Assessment of autophagy gene expression in U-138 MG and U-118 MG after PKC $\varepsilon$ downregulation

Next, we examined whether siRNA silencing of PKCe can change the expression of genes involved in autophagy pathways, using $\mathrm{qPCR}$ arrays. Considering the baseline cellular response and the risk of off- 


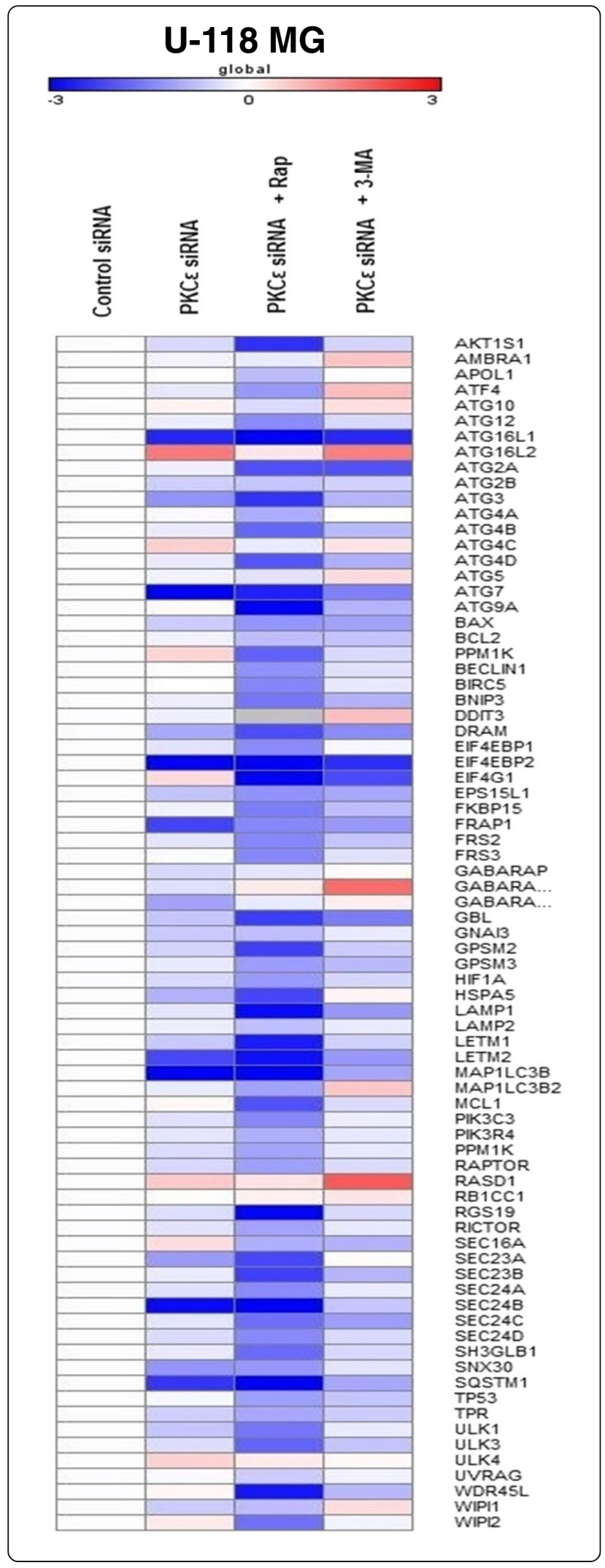

Fig. 5 Changes in autophagy gene expression in U-118 MG cells after PKC $\mathrm{P}$ downregulation and rapamycin or 3-MA treatment. The heat map shows the relative expression of human autophagy genes in U-118 MG cells transfected for $72 \mathrm{~h}$ with PKC $\varepsilon$ siRNA (PKC $\varepsilon$ siRNA) and in cells transfected and then treated for $24 \mathrm{~h}$ with rapamycin (PKC $\varepsilon$ siRNA + Rap) or 3-MA (PKC $\varepsilon$ siRNA + 3-MA). Each row represents an average gene expression normalized to the expression of the indicated gene in cells transfected with non-targeting siRNA (Control siRNA), Red color indicates genes that were upregulated, and blue color indicates genes that were downregulated. White indicates genes whose expression is unchanged in analyzed cells as compared to Control siRNA. Experiments were performed three times in duplicates

target effects, we initially compared gene expression in non-treated control cells; and non-targeting siRNA-treated cells. At the molecular level, autophagy is controlled by AuTophaGy-related genes (ATG) and their respective Atg proteins [39]. The analysis exhibited that expression level of a number of genes was reduced after the treatment with non-targeting siRNA (U-138 MG cells: ULK3, LAMP1, EIF4G1, SEC24C; U-118 MG cells: ATG16L2, AMBRA1, UKLK1, LAMP1, WDR45L, FRS3, ATG2A, RAPTOR, SEC23A, SEC24C, AKT1S1, ATG2B, MCL1, SEC24A) as well as some genes were upregulated (U-138 MG cells: UVRAG, BCL2L1, ATG16L1, MAP1LC3B3, WIPI2, BARKOR, ATG12, DRAM, SQSTM1; U-118 MG cells: BAX, DRAM, GPSM2, EIF4EBP2, ATG12, BCL2L1, SEC24B, MAP1LC3B, SQSTM1, ATG16L1, LETM2). Due to the risk of nonspecific effect, these genes were excluded from further gene expression analysis (data not shown).

Activation of autophagy involves a series of steps starting with the initiation of the phagophore. It is mediated by the Atg1/ULK kinase complex and is inhibited by mTORC1. During nucleation, the Atg proteins are recruited to the phagophore via complex integrated by Beclin1, class III phosphatidylinositol 3-kinase (PI3K), and several other proteins [40]. As shown in Fig. 4, we observed global downregulation of autophagy-related genes after $\mathrm{PKC} \varepsilon$ silencing in U-138 MG cells, compared with control siRNAtreated cells. The analysis of the panel of autophagyrelated genes demonstrated that knockdown of PKCe significantly decreased expression of $A T G 7, A T G 12$, ATG16L1, ATG9A, BARKOR, DRAM, EIF4G1 $L A M P 3, L E T M 2, U L K 1$ and MAP1LC3B genes; however, there was also a group of genes that were slightly induced, e.g., ATG4A, BNIP3, GNAI3, $S E C 24 B$, and $U L K 4$. Data revealed that the silencing of $\mathrm{PKC} \varepsilon$ in U-138 MG decreased the expression of genes involved in the formation of phagophore and autophagosome. 

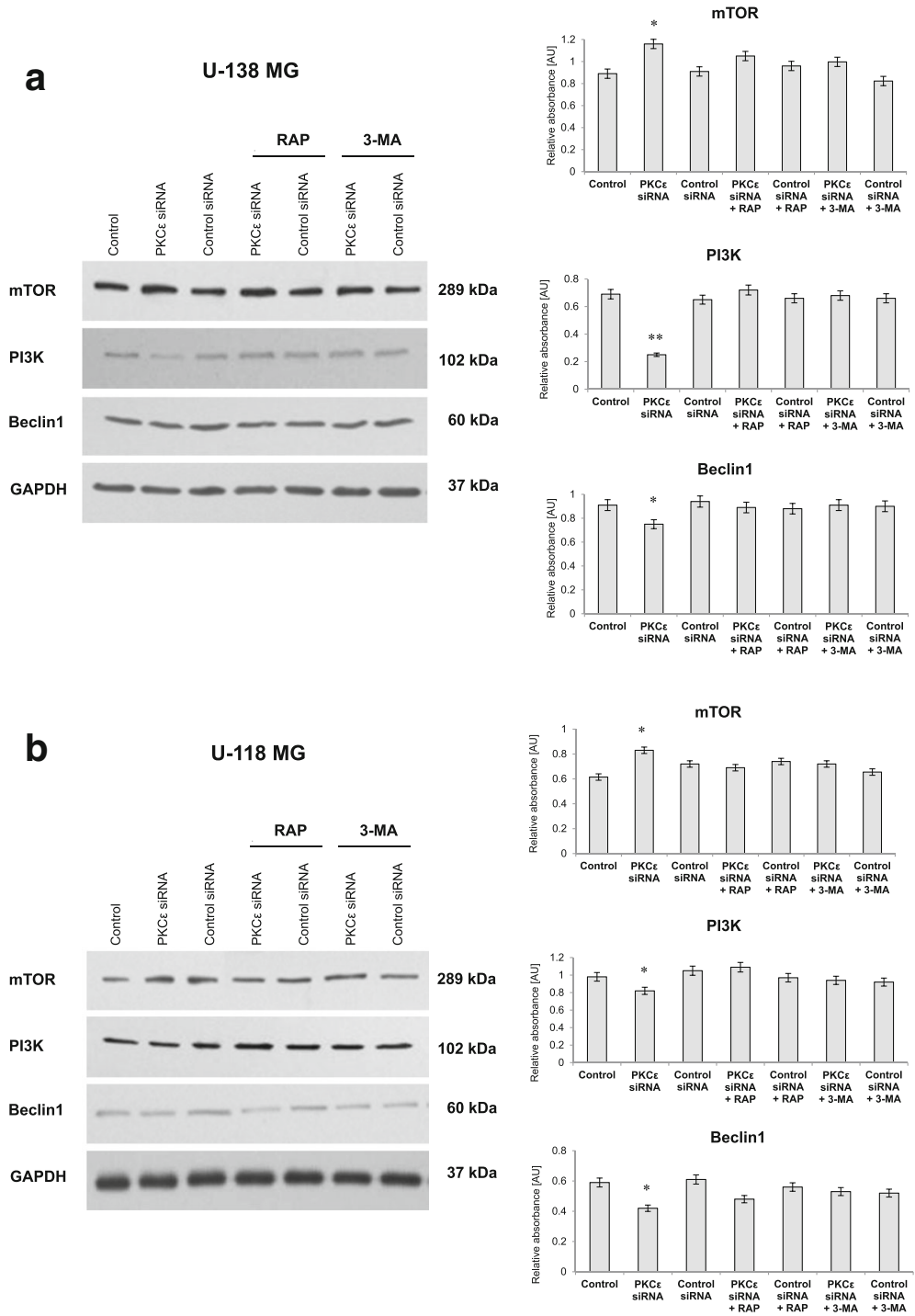

Fig. 6 Influence of PKC $\varepsilon$ downregulation and rapamycin or 3-MA treatment on protein level directly involved in autophagy activation (mTOR, PI3K, Beclin 1). a U-138 MG and $\mathbf{b}$ U-118 MG cells were transfected for $72 \mathrm{~h}$ with PKC $\varepsilon$ siRNA (PKC $\varepsilon$ siRNA) and non-targeting siRNA (Control siRNA) and then were treated for $24 \mathrm{~h}$ with rapamycin (300 nM) (PKC $\varepsilon$ siRNA + Rap) or 3-MA (5 mM) (PKC $\varepsilon$ siRNA + 3-MA). GAPDH was used as a loading control and as an internal standard. Representative blots are shown. In case of mTOR the order of bands has been changing, due to a different final construct of probe layout. The densitometric analysis represents means \pm SD of three independent experiments. ${ }^{*} P<0.05$, ** $P<0.01$ statistically significant compared to Control siRNA

To define the pathway by which knockdown of PKCE influences autophagy in glioma cells, we treated transfected cells with autophagy modulators: rapamycin and 3-methyladenine (3-MA). Rapamycin is a macrocyclic antibiotic, which is originally identified as a fungicide and immunosuppressant. Studies revealed that rapamycin specifically inhibits its target, mammalian target of rapamycin (mTOR), thereby enhancing autophagy [41]. 3-Methyladenine suppresses autophagy via the inhibition of type III phosphatidylinositol 3-kinases (PI3K). PI3K is essential in initiating autophagy through the recruitment of Atg proteins at the phagophore [42]. Interestingly, when rapamycin was used in U-138 MG PKCE siRNA cells, the expression of autophagy-related genes was significantly decreased relative to both control siRNA and PKCe siRNA cells. Downregulation was observed for the following genes: AKT1S1, ATG10, ATG12, ATG16L1, ATG3, ATG4A, ATG4B, ATG4C, ATG4D,BARKOR, BAX, BCL2L1, BNIP3, EIF4G1, PIK3C3, HSPA5, LAMP3, LETM1, MAP1LC3B, PPM1K, SEC16B, SEC23A, SEC23B, SNX30, ULK3, UVRAG, and WDR45L. In contrast, the treatment with 3methyladenine (3-MA) upregulated the expression of 

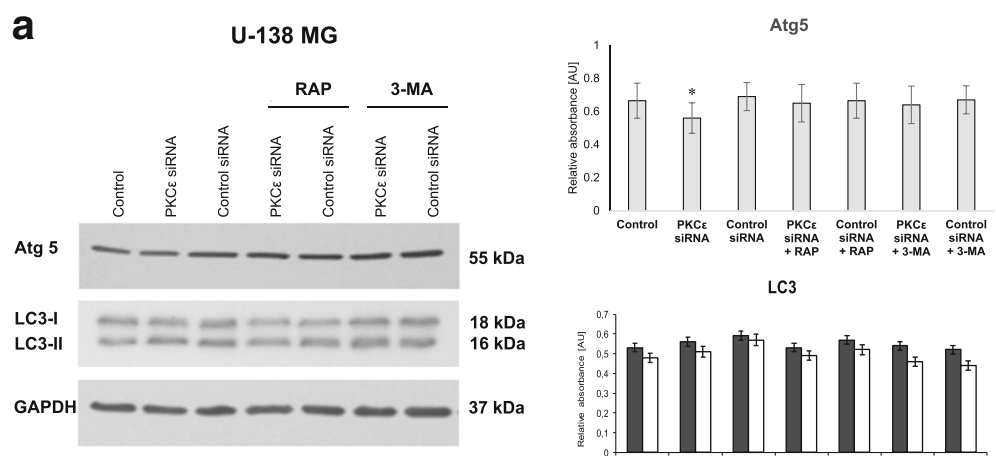

LC3
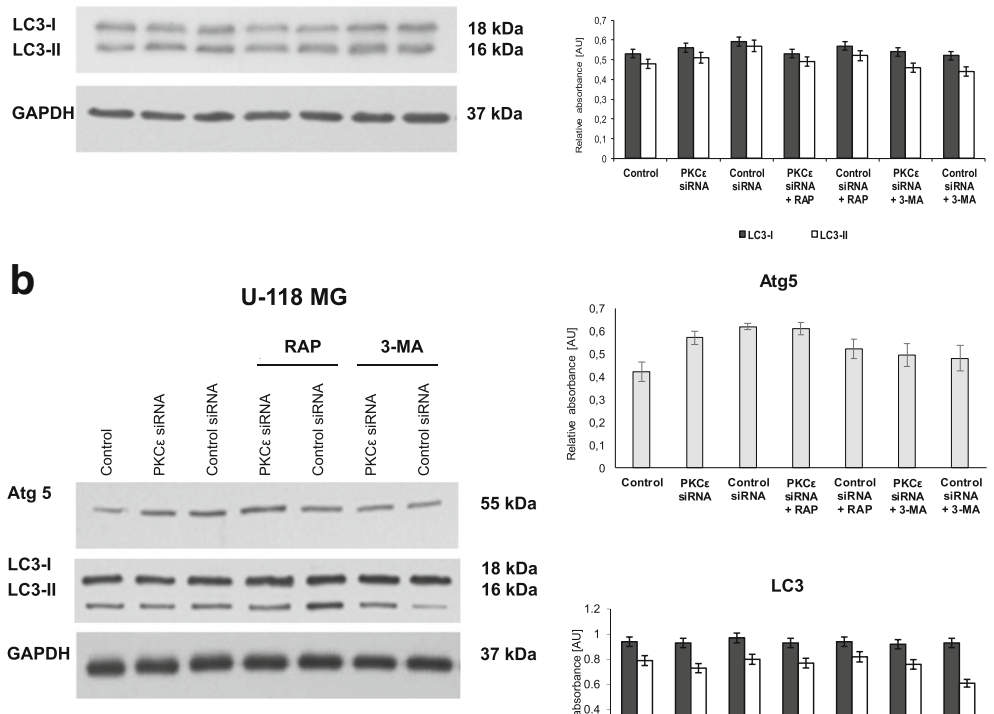

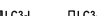
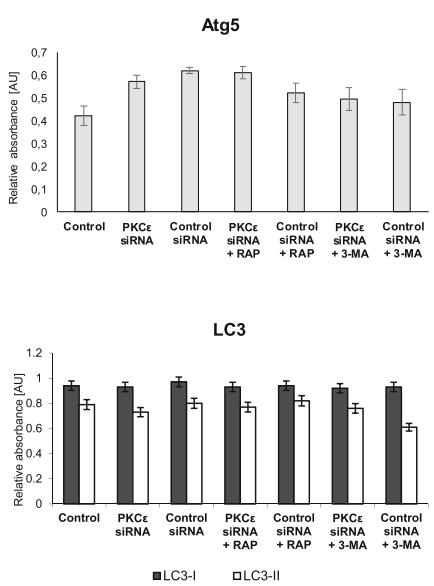

Fig. 7 Effect of PKC $\varepsilon$ downregulation and rapamycin or 3-MA treatment on proteins engaged in the formation of a double-membrane structure known as autophagosome (Atg5, LC3-II). a U-138 MG and $\mathbf{b}$ U-118 MG cells were transfected for $72 \mathrm{~h}$ with PKC siRNA (PKC $\varepsilon$ siRNA) and non-targeting siRNA (Control siRNA) and then were treated for $24 \mathrm{~h}$ with rapamycin (300 nM) (PKC $\varepsilon$ siRNA + Rap) or 3-MA (5 mM) (PKC siRNA + 3-MA). GAPDH was used as a loading control and as an internal standard. Representative blots are shown. The densitometric analysis represents means \pm SD of three independent experiments. * $P<0.05$, statistically significant compared to Control siRNA

ATF4, ATG16L1, ATG16L2, DDIT3, GABARAPL1, GNAI3, MAP1LC3A, RASD1, SEC16B, SEC23A, ULK4, and WIPI2 genes in U-138 MG PKCE siRNA cells compared to control siRNA and PKCe siRNA cells (Fig. 4).

Next, we analyzed the expression of autophagyrelated genes in U-118 MG cells in the same experimental model: the $\mathrm{PKC} \varepsilon$ siRNA transfection followed by rapamycin or 3-MA treatment. The analysis demonstrated that siRNA silencing of PRKCE in U-118 MG cells caused a significant decrease in numerous autophagy-related gene expression compared to control siRNA-treated cells (Fig. 5). Genes ATG16L1, ATG 3, ATG7, DRAM, EIF4EBP2, FRAP1, LETM2, MAP1LC3B, SEC23A, $S E C 24 B, S N X 30$, and SQSTM1 were significantly downregulated. Silencing of PRKCE gene in U-118 MG cells also resulted in upregulation of $A T G 16 L 2$, ATG4C, EIF4G1, PPM1K, RASD1, SEC16A and ULK4 genes.
Similar to the results for U-138 MG cell line, rapamycin treatment of U-118 MG cells after PKCe downregulation resulted in the inhibition of expression of most of the analyzed genes (AKT1S1, ATF4, ATG12, ATG16L1, $A T G 2 A, A T G 3, A T G 4 A, A T G 4 B, A T G 4 D, A T G 7$, ATG9A, BAX, PPM1K, BECLIN1, BIRC5, BNIP3, DRAM,EIF4GP1 EIF4GP2, EIF4G1, EPS15L1, FKBP15, FRAP1, FRS2, FRS3, GBL, GPSM2, HSPA5, LAMP1, LETM1, LETM2, MAP1LC3B, MCL1, PIK3C3, RGS19, SEC23A, SEC23B, SEC24B, SEC24C, SH3GLB1, SQSTM1, ULK1, ULK3, WDR45L, WIPI2). Moreover, 3MA treatment induced expression of several genes (AMBRA1, ATF4, ATG10, ATG16L2, ATG5, DDIT3, GABARAPL1, MAP1LC3B2, RASD1) (Fig. 5).

After PKCE siRNA treatment we observed downregulation of genes involved in autophagy pathways. In addition, we showed that positive autophagy regulator, rapamycin caused an increase in downregulation of autophagy-related genes in PKCe siRNA cells (Figs. 2, 4 , and 5). 

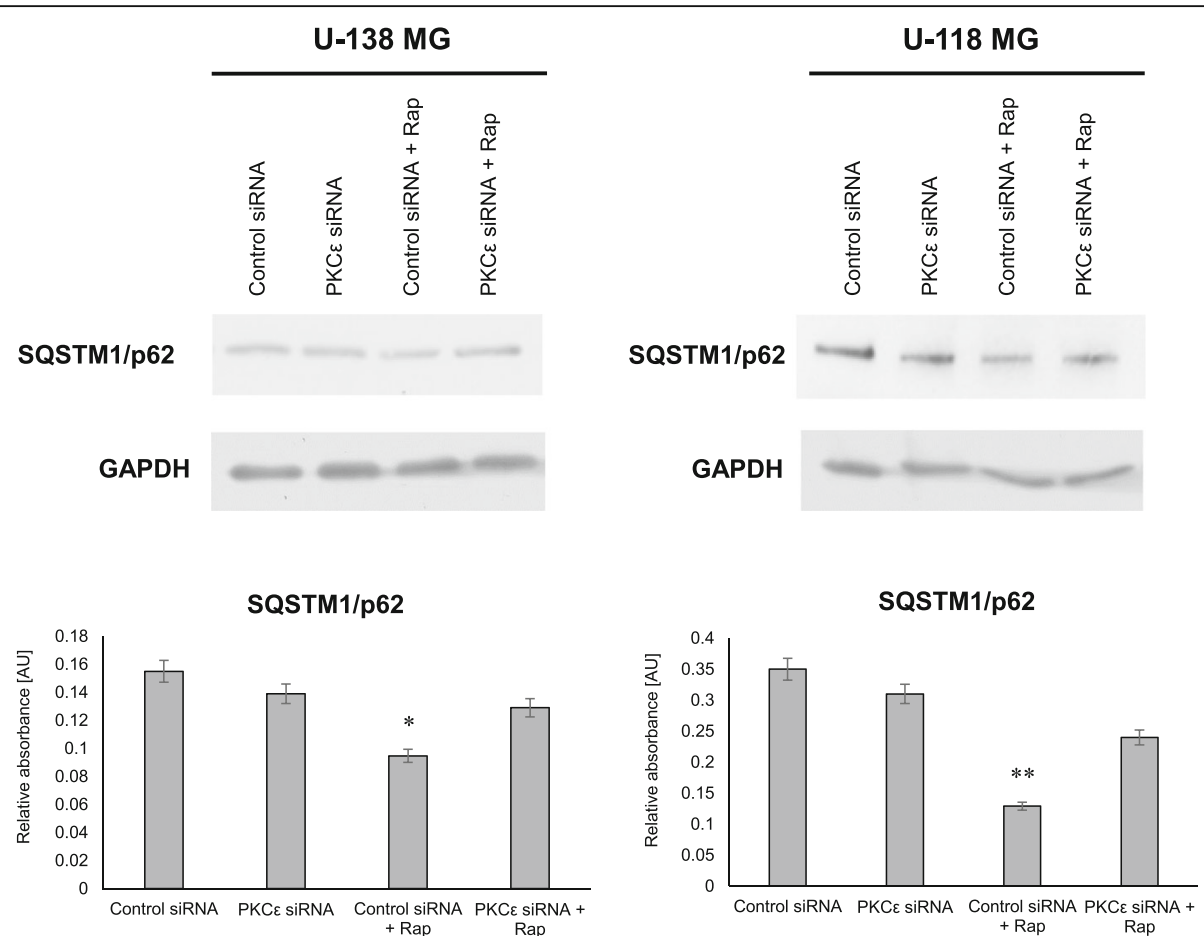

Fig. 8 Modulation SQSTM1/p62 after PRKCE silencing and rapamycin treatment. a U-138 MG and b U-118 MG cells were transfected for $72 \mathrm{~h}$ with PKC $\varepsilon$ siRNA (PKCE siRNA) and non-targeting siRNA (Control siRNA) and then were treated for $24 \mathrm{~h}$ with rapamycin (300 nM). GAPDH was used as a loading control and as an internal standard. Representative blots are shown. The densitometric analysis represents means \pm SD of three independent experiments. * $P<0.05$, statistically significant compared to Control siRNA

\section{Alterations of autophagy-related proteins after PKC $\varepsilon$ downregulation}

In order to examine the role of PKC $\varepsilon$ in autophagy pathways in glioma cells, we evaluated the impact of siRNA silencing of $\mathrm{PKC \varepsilon}$ on the level of crucial autophagic proteins. Autophagy is induced by an initial membrane nucleation step that requires the ULK1 complex and a class III phosphoinositide 3-kinase complex including Beclin1. Beclin1 is a protein that promotes the formation of the Beclin-1-Vps34-Vps15 complex triggering the autophagy protein cascade [43]. This protein complex recruits many of the key autophagic proteins required for proper initiation of autophagosome formation, e.g. ubiquitin-like conjugation systems Atg5-Atg-12 and LC3 [44]. Several studies have demonstrated that mTOR (mammalian target of rapamycin) kinase is a central checkpoint that downregulates autophagy [45-47]. In our study, we classified the crucial protein markers of autophagy into three groups: I-proteins involved directly in autophagy initiation (mTOR, PI3K, Beclin1), II-proteins engaged in the formation of a double-membrane structure known as autophagosome (Atg5, LC3-II), and wellcharacterized autophagosome substrate (p62/SQSTM1), III-protein that regulates autophagy process (Bcl-2).

As presented in Fig. 6a and b knockdown of PKCe drastically reduced the level of PI3K and Beclin1 protein in U-138 MG and U-118 MG cells compared to control siRNA cells. Moreover, in those cells, the level of antiautophagic mTOR was increased.

Next, we analyzed the level of these same proteins in U138 MG and U-118 MG cells after siRNA silencing of PRKCE followed by 24-h treatment with rapamycin (300 $\mathrm{nM})$ or 3-MA $(5 \mathrm{mM})$. In both glioblastoma cell lines, the analysis demonstrated no significant changes in the level of PI3K, Beclin1, and mTOR compared to control siRNA cells (Fig. 6a and b).

Thereafter, we assessed changes in the second group of autophagy markers consisted of proteins engaged in the formation of a double-membrane structure known as autophagosome (Atg5, LC3-II). Atg5 protein creates a complex with Atg12 and mediates LC3 conversion and by that autophagosome formation [40]. As shown in Fig. 7a and $\mathrm{b}$ PKC $\varepsilon$ downregulation in U-138 MG and U-118 MG cells led to decreased levels of Atg5.

Next, we analyzed the accumulation of LC3-II, the lipidated form of LC3 associated with the autophagosome membrane. The amount of LC3-II reflects the number of autophagosomes [45]. As shown in Fig. 7a and $b$, we observed no significant changes in the level of LC3-II in PKCe siRNA cells compared to control siRNA cells. Moreover, our study showed alternations in the level of LC3-II protein under the influence of 


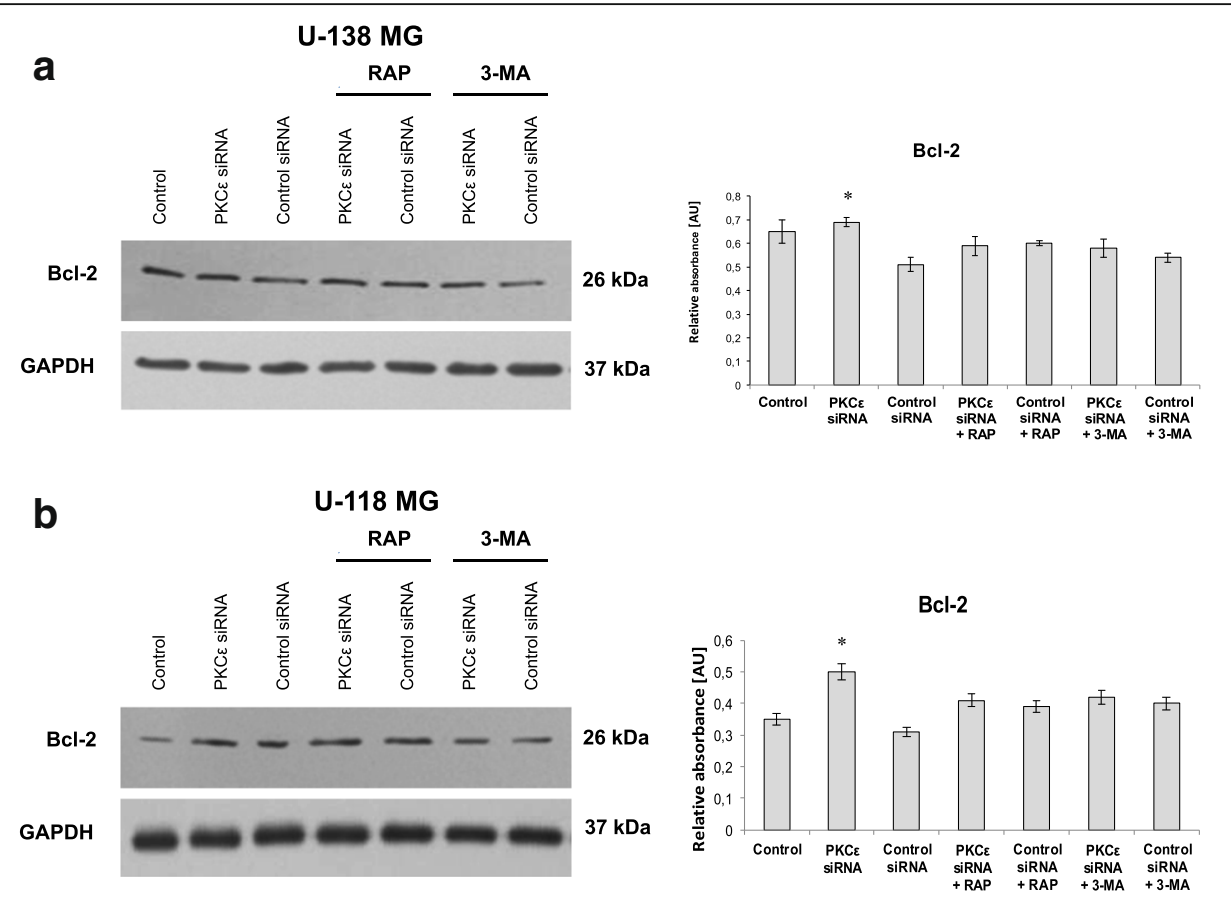

Fig. 9 Effect of PKCE downregulation and rapamycin or 3-MA treatment on $\mathrm{BCl}-2$, a protein that regulates autophagy process. a U-138 $\mathrm{MG}$ and $\mathbf{b} \mathrm{U}-118$ MG cells were transfected for $72 \mathrm{~h}$ with PKC $\varepsilon$ siRNA (PKC $\varepsilon$ siRNA) and non-targeting siRNA (Control siRNA) and then were treated for $24 \mathrm{~h}$ with rapamycin (300 nM) (PKC ع siRNA + Rap) or 3-MA (5 mM) (PKC $\varepsilon$ siRNA + 3-MA). GAPDH was used as a loading control and as an internal standard. Representative blots are shown. The densitometric analysis represents means \pm SD of three independent experiments. ${ }^{*} P<0.05$, statistically significant compared to Control siRNA

modulators of autophagy process (rapamycin and 3-MA) in control siRNA cells (Fig. 7b).

p62, also known as SQSTM1/sequestome 1, serves as a link between LC3 and ubiquitinated substrates and is efficiently degraded by autophagy. Autophagic suppression correlates with an increased p62 level, and similarly, autophagic activation correlates with a decreased p62 level. Thus, the measurement of the cellular p62 level appears to correlate well with other markers of autophagic flux. Therefore, is recommended that to monitor autophagy use combination of p62 level and LC3-II turnover [48].

As shown in Fig. 8 we observed lack of autophagy activation after treatment with rapamycin in PKCe siRNA cells, but in control siRNA cells there was a decrease in a p62 level that indicates autophagy activation. Our results suggest that PKCE siRNA transfection inhibited rapamycin-induced autophagy in both glioblastoma cell lines with overexpressed PKC\&.

Next, we investigated the protein that takes part in the regulation of autophagy process-Bcl-2. As shown in Fig. 9a and b, knockdown of PKCe markedly enhanced the protein expression of $\mathrm{Bcl}-2$ in both glioblastoma cell lines. Interaction Beclin1 with anti-apoptotic Bcl-2 prevents Beclin1 from assembling the pre-autophagosomal structure thus leads to inhibition of autophagy [49].

\section{Endogenous immunofluorescence of LC3}

In order to understand autophagy dynamics, we assessed the endogenous immunostaining of LC3 protein. The HeLaPKCEA/E subline treated with doxycycline (Dox) and rapamycin (Rap) served as a positive control for autophagosome formation. As shown in Fig. 10a after treatment with rapamycin autophagosome accumulation has not been observed in glioblastoma cell lines treated with PKCE siRNA. In contrast treatment with rapamycin increased presence of autophagosome in control siRNA cells. The images recorded by fluorescence microscope were analyzed the variation of number and area of vesicles (represent autophagosomes) by AUTOCOUNTER (ImageJ JavaScript software) [50] (Fig. 10b). The received numerical data confirmed observed changes. The PKC $\varepsilon$ downregulation caused a decrease in number and size of vesicles and attenuation of the rapamycin effect. Observed changes had the same tendencies in all carried analysis.

\section{Evaluation of the level and phosphorylation of Akt}

In the present study, after siRNA silencing of PRKCE, we analyzed the protein level and phosphorylation of Akt in U-138 MG and U-118 MG cells. As presented in Fig. 11 the silencing of $\mathrm{PKC \varepsilon}$ significantly decreased the level of Akt compared to control siRNA cells in both 


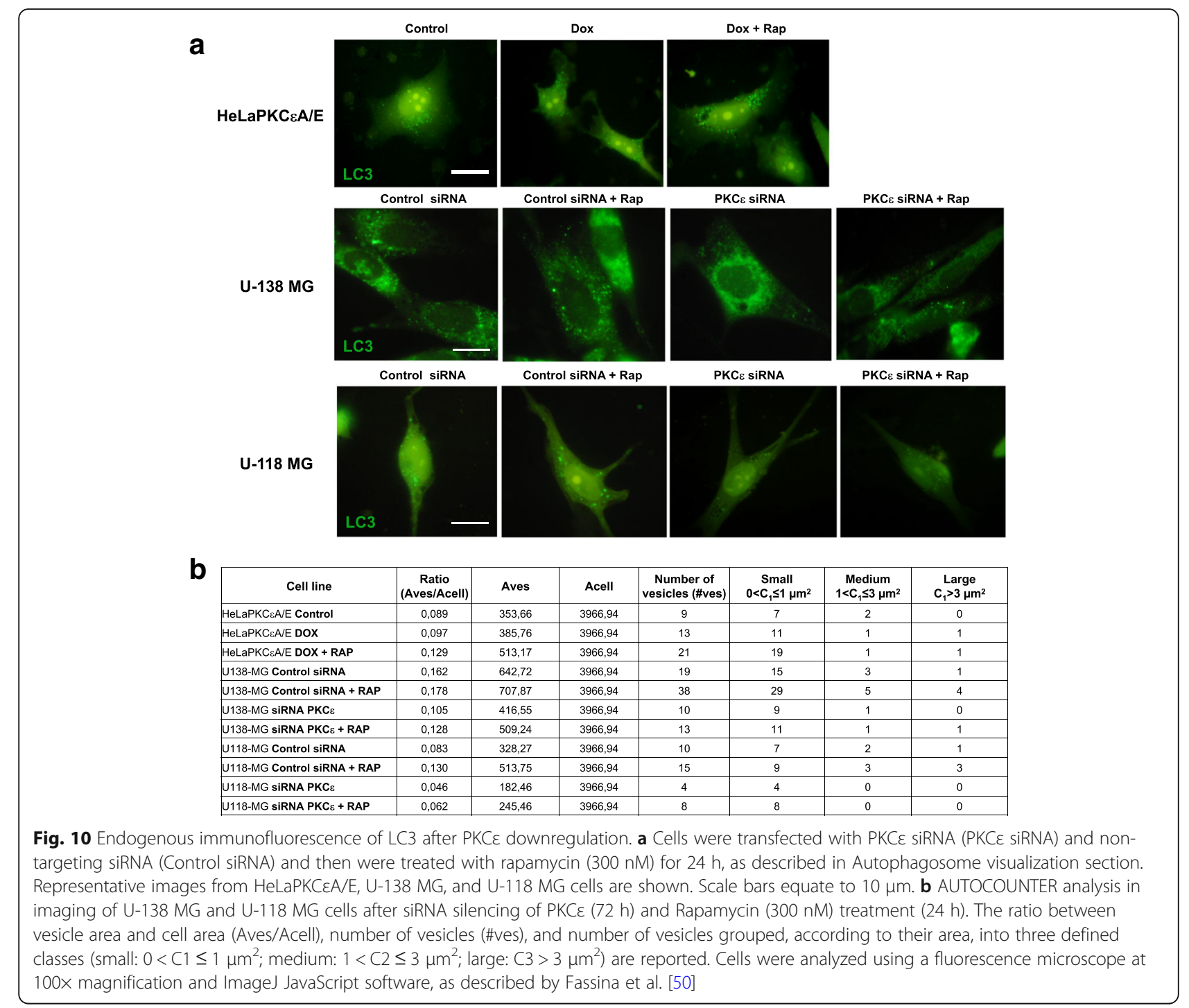

tested cell lines. Next, we investigated phosphorylation of Akt at Ser 473. We observed that PKCe silencing decreased Akt phosphorylation compared to control siRNA cells. Additionally, rapamycin treatment resulted in the lower level of phosphorylation of Akt compared to control siRNA cells. The analysis of 3-MA treatment after knockdown $\mathrm{PKC \varepsilon}$ demonstrated no significant changes in the Ser 473 phosphorylation of Akt compared to control siRNA cells. These results indicated that activation of the $\mathrm{PKC} \varepsilon$ pathway could contribute to activations of PI3K/Akt pathway, through interactions between $\mathrm{PKC} \varepsilon$ and Akt.

Assesment of phosphorylation of focal adhesion kinase in U-138 MG and U-118 MG after PKC $\varepsilon$ downregulation

The cell adhesion to the extracellular matrix (ECM) plays a critical role in the regulation of essential cellular functions [51]. Focal adhesion kinase (FAK) mediates a number of signaling pathways associated with cell adhesion. The network contains many classes of signaling molecules. FAK is a cytoplasmic nonreceptor tyrosine kinase which transduces the matrix-dependent effects on cell proliferation, migration, and survival [52]. Phosphorylation of FAK at tyrosine 397 plays an essential role in tumor cell signaling and can be induced by growth factors and mechanical stress [53].

The link between PKCe and FAK was demonstrated by Heidkamp et al. [54]. They showed that overexpression of caPKC (constitutively active $\mathrm{PKC} \varepsilon$ ) increased both Y397pFAK and total FAK.

We performed a study on the role of PKCE in the adhesion of glioblastoma cells. The attachment assay was performed as shown in Fig. 12a and b, PKCe downregulation markedly diminished cell adhesion in both glioblastoma cell lines. In U-138 MG and U-118 MG cells, the PKCe siRNA transfection caused about 

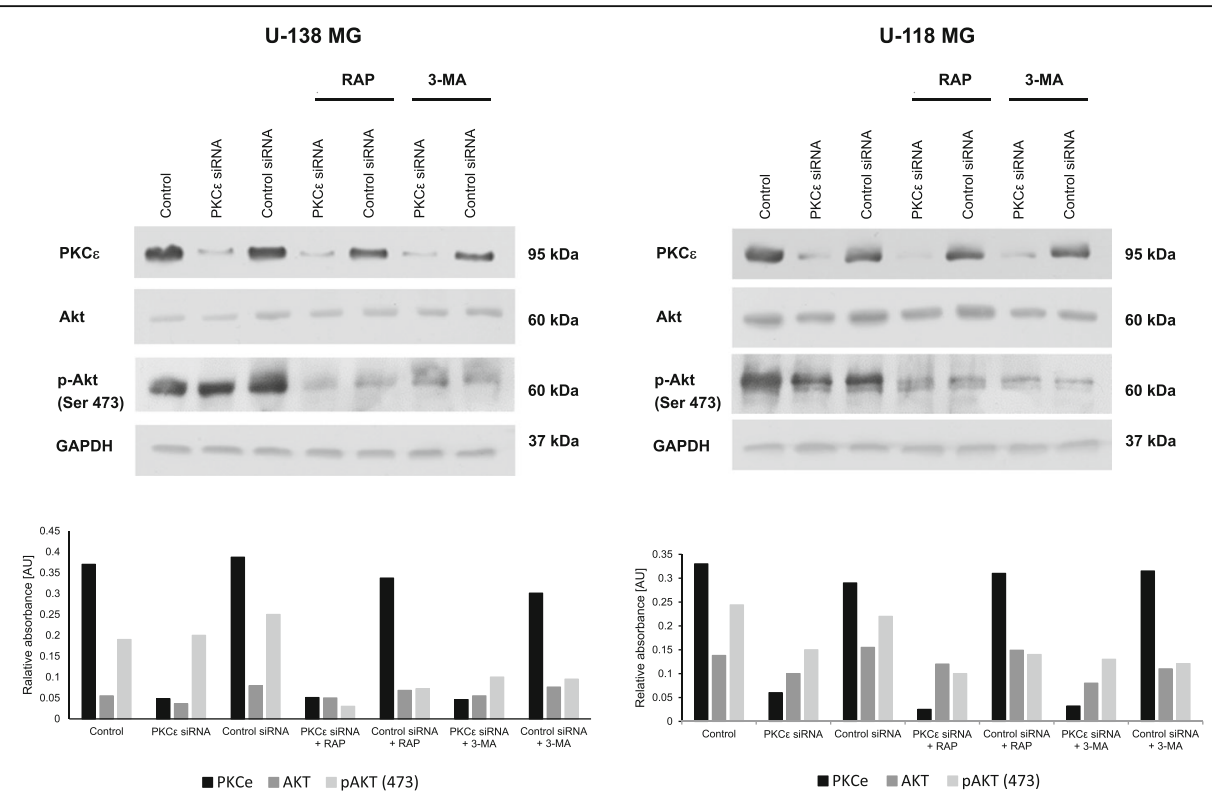

Fig. 11 Knockdown of PKC diminishes the level and phosphorylation of Akt in glioma cells. a U-138 MG and b U-118 MG were transfected for $72 \mathrm{~h}$ with PKC $\varepsilon$ siRNA and Control siRNA and then were treated for $24 \mathrm{~h}$ with rapamycin (300 nM) or 3-MA (5 mM). GAPDH was used as a loading control and as an internal standard. Representative blots are shown. The densitometric analysis represents means \pm SD of three

independent experiments

$41 \%$ and $50 \%$ inhibition of cell adhesion after $60 \mathrm{~min}$ of incubation and 39\% and 39\% after $180 \mathrm{~min}$ of incubation, respectively (Fig. 12a and b). Western blot analysis revealed that $\mathrm{PKC} \varepsilon$ downregulation significantly decreased phosphorylation of FAK at Tyr-397 and Tyr-576/577 in U-138 MG and U-118 MG cells. We also observed a reduction in total FAK protein level in both tested cell lines (Fig. 12c). Our study showed that downregulation of $\mathrm{PKC} \varepsilon$ was lowering the adhesion of glioblastoma cells, accompanied by the decrease in total FAK protein level and FAK phosphorylation.

\section{Discussion}

Numerous cancer processes are modulated by PKC $\varepsilon$ isoform activity, e.g., migration, adhesion, proliferation, and differentiation [31]. Studies reported that PKCe suppresses apoptosis and promotes tumor growth, and thus shows the greatest oncogenic potential of the PKC family [12]. High expression of $\mathrm{PKC} \varepsilon$ was found in cancers of the breast, prostate, lung, leukemia, and glioblastomas [27, 31]. It has been shown that PKCe is overexpressed in many astroglial cell lines in comparison to normal astrocytes and contributes to establishing an aggressive phenotype $[5,55]$. Since the role of PKCe in the apoptosis of glioma cells have been studied before [12], we aimed to target non-apoptotic death pathway-autophagy involved in survival, progression, and resistance of glioma cells [56]. To evaluate the correlation between high expression of PKCE and autophagy pathways in glioblastomas, we investigated the influence of $P R K C E$ silencing on global expression of genes engaged in the autophagy process. In this study, we demonstrated that two glioblastoma cell lines such as U-138 MG and U118 MG classified as grade IV astrocytoma have high basal level of $\mathrm{PKC} \varepsilon$ protein.

We found that in selected glioblastoma cell lines, genes associated with autophagy induction are upregulated, suggesting that autophagy in those cells acts as a tumor-promoting factor. Increased basal levels of autophagy were also detected earlier in breast, pancreatic, and astrocytoma cancer [57-59]. Moreover, increased expression of autophagy markers was found to be correlated with poor survival and radiotherapy/ chemotherapy response in astrocytoma patients [60]. Additionally, PKC $\varepsilon$ has been implicated in the regulation of both cell survival and apoptosis in various cellular systems. In our study, the correlation between PKC $\varepsilon$ and autophagy was confirmed with downregulation of autophagy related genes after silencing PKC $\varepsilon$. Thereafter, we found that knockdown of $\mathrm{PKC \varepsilon}$ induced a decrease in the expression of Beclin1, Atg5, PI3K, whereas the expression of other autophagyrelated proteins mTOR and $\mathrm{Bcl} 2$ was increased. Obtained data thus far suggest a connection between $\mathrm{PKC} \varepsilon$ expression and autophagic pathway.

It is important to include autophagy modulators due to the assessment of changes in autophagy pathways. To delineate the molecular mechanisms involved in the autophagy interruption induced by 


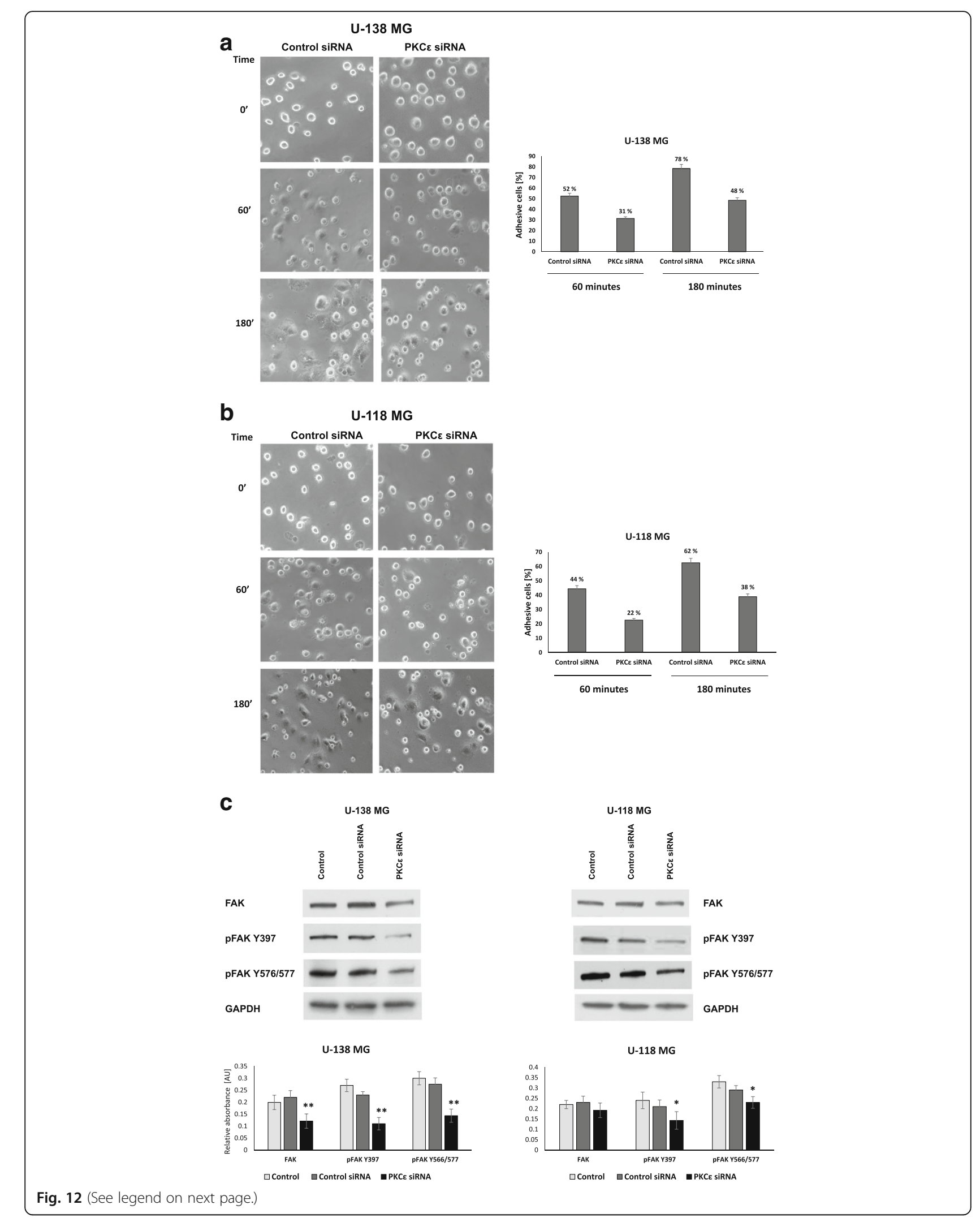


(See figure on previous page.)

Fig. 12 Effect of PKC $\varepsilon$ downregulation on the adhesion of glioblastoma cells. a. U-138 MG and b U-118 MG cells were transfected for $72 \mathrm{~h}$ with PKC $\varepsilon$ siRNA (PKC $\varepsilon$ siRNA) and Control siRNA and then were seeded in culture plates coated with Matrigel (Corning Life Sciences, NY, USA). The photos represent cell adhesion under the microscope at 100 x magnification field. c Evaluation of FAK expression in U-138 MG and U-118 MG cells with knockdown PKCE. Total protein expression and FAK phosphorylation at Tyr-397/Tyr-576/577 were assessed. GAPDH was used as a loading control and as an internal standard. Representative blots are shown. The densitometric analysis represents means \pm SD of three independent experiments. ${ }^{*} P<0.05$, statistically significant compared to Control siRNA

silencing of PKCe, we examined the influence of positive autophagy regulator rapamycin. Treatment of control siRNA glioma cells with that activator induced autophagosome formation and an increase of LC3-II level and caused a decrease in the expression of p62. In contrast, in rapamycin-treated PKCe siRNA cells, we did not observe an increase in the presence of autophagic vacuoles and changes in LC3-II and p62 protein levels.

Moreover, in our studies, we discovered that the silencing of PRKCE gene and specifically decline of the expression of $\mathrm{PKC \varepsilon}$ caused a significant diminution in the Akt phosphorylation of Ser in position 473 and expression of Akt protein level in both glioblastoma cells. The serine/threonine kinase Akt is widely acknowledged as a proto-oncogene. It is an essential component in PI3K/Akt/mTOR pathway. The PI3K/ Akt/mTOR pathway is a crucial regulator of cell growth, including proliferation, growth, differentiation, and survival. Therefore, abnormal activation of PI3K/ Akt/mTOR signaling pathway is commonly involved in the development and progression of various tumors [61]. The activation of PI3K phosphorylates and activates Akt, which have numerous downstream effects including activating mTOR [62]. Studies by Yang F and Gao JY showed that inhibition of PI3K/Akt/ mTOR pathway by an inhibitor (BEZ235) or PI3KCA knockdown (shRNA transduction) significantly suppressed cell proliferation, migration, invasion and induced apoptosis human colon cancer cells [63].

The FAK protein is overexpressed in many cancers, including neuroblastoma, glioblastoma, breast cancer, colorectal cancer, pancreatic cancer, lung cancer, ovarian cancer [64, 65]. FAK autophosphorylation at Tyr397 (Y397 FAK) creates a binding site for c-Src that phosphorylates FAK at Tyr576 (Y576 FAK) and Tyr577 (Y577 FAK), promoting maximal FAK catalytic activity. In fact, FAK phosphorylation at Y576 and Y577 is required for maximal Y397 phosphorylation [66]. Our studies showed that PKCE downregulation caused reduction of adhesion of U-138 MG and U-118 MG cells by diminished activation and level of FAK. Many studies show that cancer cells with reduced potential for adhesion consequently lose functional links with the extracellular matrix. Therefore, they cannot move and adhere to other locations, which prevent the development of metastases $[67,68]$. Studies by Nam JK and co-workers confirm that histone deacetylase inhibitor suppresses cell migration and invasion in human glioma cells by inhibiting FAK/STAT3 signaling [67].

These results together with enhanced downregulation of autophagy-related genes in response to rapamycintreatment in PKCE siRNA cells suggest that the expression of $\mathrm{PKC} \varepsilon$ is essential for the autophagic signal transduction pathways. Due to the fact that GB cell lines not fully mimic GB tumors this subject needs further investigation [69]. Several studies have shown that upregulation of autophagy can function as a prosurvival pathway in the presence of chemotherapy and enhance tumor resistance to anticancer therapies [70,71].

\section{Conclusion}

In summary, our results identify an important role of $\mathrm{PKC} \varepsilon$ in the autophagy and adhesion that may, more importantly, someday providing a novel therapeutic strategy witch improve the survival of patients with gliomas.

\section{Abbreviations}

3-MA: 3-methyladenine; ATG: AuTophaGy-related genes; ATO: Arsenic trioxide; Dox: Doxycycline; GB: Glioblastoma; mTOR: mammalian target of rapamycin; PI3K: Phosphatidylinositol 3-kinase; PKCE: Protein kinase C epsilon; Rap: Rapamycin; TRAIL: TNF-related apoptosis-inducing ligand

\section{Acknowledgements}

We would like to thank Sergio Comincini and Lorenzo Fassina for made available the AUTOCOUNTER, an ImageJ JavaScript, what has enabled the assessment of LC3 fluorescence level.

\section{Funding}

The study was supported by funds from the National Science Center, the Republic of Poland, grant no. 2011/03/B/NZ7/06244 and statutory subsidies of Department of Clinical Chemistry and Molecular Diagnostics, Poznan University of Medical Sciences no. 502-01-03318432-08035. The funding bodies had no role in the design of the study and collection, analysis, and interpretation of data and in writing the manuscript.

\section{Availability of data and materials}

All data are included in the paper.

\section{Authors' contributions}

ET designed the study, ET and AR were involved in the technique of transfection and autophagosome visualisation; ET, AR, and NK performed qPCR; ET performed Western blot, attachment assay, and statistical analysis; JB donated all the glioma cell lines; JH donated the HeLaPKCEA/E; ET and MR drafted the paper. All authors read and approved the final version of the manuscript.

Ethics approval and consent to participate Not applicable. 


\section{Consent for publication}

Not applicable.

\section{Competing interests}

The authors declare that they have no competing interests.

\section{Publisher's Note}

Springer Nature remains neutral with regard to jurisdictional claims in published maps and institutional affiliations.

\section{Author details}

'Department of Clinical Chemistry and Molecular Diagnostics, Poznan University of Medical Sciences, Przybyszewskiego 49 St., 60-355 Poznan, Poland. ${ }^{2}$ Biocenter, Division of Medical Biochemistry, Innsbruck Medical University, Innrain 80-82, A-6020 Innsbruck, Austria. ${ }^{3}$ NanoBioMedical Center, Adam Mickiewicz University in Poznan, Poznan, Poland. ${ }^{4}$ Institute of Bioorganic Chemistry, Polish Academy of Sciences, Poznan, Poland.

\section{Received: 5 October 2016 Accepted: 5 February 2018}

\section{Published online: 13 February 2018}

\section{References}

1. Walid MS. Prognostic factors for long-term survival after glioblastoma. Perm J. 2008;12(4):45-8.

2. Ramirez YP, Weatherbee $J$, Wheelhouse RT, Ross AH. Glioblastoma multiforme therapy and mechanisms of resistance. Pharmaceuticals. 2013; 6(12):1475-506.

3. Inda MM, Bonavia R, Seoane J. Glioblastoma multiforme: a look inside its heterogeneous nature. Cancer. 2014;6(1):226-39.

4. Mao H, Lebrun DG, Yang J, Zhu VF, Li M. Deregulated signaling pathways in glioblastoma multiforme: molecular mechanisms and therapeutic targets. Cancer Investig. 2012;30(1):48-56.

5. Sharif TR, Sharif M. Overexpression of protein kinase C epsilon in astroglial brain tumor derived cell lines and primary tumor samples. Int J Oncol. 1999; 15(2):237-43.

6. Kang JH. Protein Kinase C (PKC) Isozymes and Cancer. New Journal of Science. 2014; ID 231418.

7. Jain K, Basu A. The multifunctional protein kinase C- $-\varepsilon$ in cancer development and progression. Cancer. 2014;6:860-78.

8. Wang H, Gutierrez-Uzquiza A, Garg R, et al. Transcriptional regulation of oncogenic protein kinase C $€$ (PKCE) by STAT1 and Sp1 proteins. J Biol Chem. 2014;289(28):19823-38.

9. $\mathrm{Yu}$ L, Strandberg L, Lenardo MJ. The selectivity of autophagy and its role in cell death and survival. Autophagy. 2008;4(5):567-73.

10. Jiang H, White EJ, Conrad C, Gomez-Manzano C, Fueyo J. Autophagy pathways in glioblastoma. Methods Enzymol. 2009;453:273-86.

11. Aoki H, Kondo Y, Aldape K, Yamamoto A, Iwado E, Yokoyama T, Hollingsworth EF, Kobayashi R, Hess K, Shinojima N, Shingu T, Tamada Y, Zhang L, Conrad C, Bogler O, Mills G, Sawaya R, Kondo S. Monitoring autophagy in glioblastoma with antibody against isoform B of human microtubule-associated protein 1 light chain 3. Autophagy. 2008;4(4):467-75

12. Li C, Liu Y, Liu H, Zhang W, Shen C, Cho K, Chen X, Peng F, Bi Y, Hou X, Yang Z, Zheng Z, Wang K, Wang X, Zhang J, Zhong C, Zou H, Zhang X, Zhao S. Impact of autophagy inhibition at different stages on cytotoxic effect of autophagy inducer in glioblastoma cells. Cell Physiol Biochem. 2015:35(4):1303-16.

13. Kahana S, Finniss S, Cazacu S, Xiang C, Lee HK, Brodie S, Goldstein RS, Roitman V, Slavin S, Mikkelsen T, Brodie C. Proteasome inhibitors sensitize glioma cells and glioma stem cells to TRAIL-induced apoptosis by PKC $\varepsilon$ dependent downregulation of AKT and XIAP expressions. Cell Signal. 2011; 23(8):1348-57.

14. Marte BM, Downward J. PKB/Akt: connecting phosphoinositide 3-kinase to cell survival and beyond. Trends Biochem Sci. 1997:22:355-8.

15. Okhrimenko H, Lu W, Xiang C, Hamburger N, Kazimirsky G, Brodie C. Protein kinase C-epsilon regulates the apoptosis and survival of glioma cells. Cancer Res. 2005;65(16):7301-9.

16. Franke TF, Hornik CP, Segev L, Shostak GA, Sugimoto C. PI3K/Akt and apoptosis: size matters. Oncogene. 2003;22:8983-98.

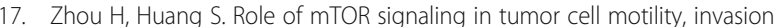
and metastasis. Curr Protein Pept Sci. 2011;12(1):30-42.
18. Feldman ME, Apsel B, Uotila A, Loewith R, Knight ZA, Ruggero D, Shokat KM. Active-site inhibitors of mTOR target rapamycin-resistant outputs of mTORC1 and mTORC2. PLOS Biol. 2009;7:e1000038.

19. Vanhaesebroeck B, Alessi DR. The PI3K-PDK1 connection: more than just a road to PKB. Biochem J. 2000;346:561-76.

20. Maiuri MC, Zalckvar E, Kimchi A, Kroemer G. Self-eating, and self-killing: crosstalk between autophagy and apoptosis. Nat Rev Mol Cell Biol. 2007; 8(9):741-52.

21. Toton E, Romaniuk A, Budzianowski J, Hofmann J, Rybczynska M. Zapotin $\left(5,6,2^{\prime}, 6^{\prime}\right.$-tetramethoxyflavone) modulates the crosstalk between autophagy and apoptosis pathways in cancer cells with overexpressed constitutively active PKC€. Nutr Cancer. 2016;68(2):290-304.

22. Chomczynski P, Sacchi N. Single-step method of RNA isolation by acid guanidinium thiocyanate-phenol-chloroform extraction. Anal Biochem. 1987; 162(1):156-9.

23. Reardon DA, Ligon KL, Chiocca EA, Wen PY. One size should not fit all: advancing toward personalized glioblastoma therapy. Discov Med. 2015 19(107):471-7

24. Yu Z, Xie G, Zhou G, Cheng Y, Zhang G, Yao G, Chen Y, Li Y, Zhao G. NVPBEZ235, a novel dual PI3K-mTOR inhibitor displays anti-glioma activity and reduces chemoresistance to temozolomide in human glioma cells. Cancer Lett. 2015; https://doi.org/10.1016/j.canlet.2015.07.007.

25. Gorin MA, Pan Q. Protein kinase C epsilon: an oncogene and emerging tumor biomarker. Mol Cancer. 2009;8:9. https://doi.org/10.1186/14764598-8-9.

26. Aziz MH, Hafeez BB, Sand JM, Pierce DB, Aziz SW, Dreckschmidt NE, Verma AK. Protein kinase Cvarepsilon mediates Stat3Ser727 phosphorylation, Stat3regulated gene expression, and cell invasion in various human cancer cell lines through integration with MAPK cascade (RAF-1, MEK1/2, and ERK1/2) Oncogene. 2010;29(21):3100-9. https://doi.org/10.1038/onc.2010.63.

27. Garczarczyk D, Toton E, Biedermann V, Rosivatz E, Rechfeld F, Rybczynska M, Hofmann J. Signal transduction of constitutively active protein kinase C epsilon. Cell Signal. 2009;21(5):745-52.

28. Xiao H, Goldthwait DA, Mapstone T. The identification of four protein kinase $\mathrm{C}$ isoforms in human glioblastoma cell lines: PKC alpha, gamma, epsilon, and zeta. J Neurosurg. 1994:81(5):734-40.

29. Sharif TR, Sharif M. Overexpression of protein kinase $C \varepsilon$ in astroglial brain tumor derived cell lines and primary tumor samples. Int J Oncol. 1999:15: 237-43.

30. Cacace AM, Ueffing M, Philipp A, Han EK, Kolch W, Weinstein IB. PKC epsilon functions as an oncogene by enhancing activation of the Raf kinase. Oncogene. 1996;13(12):2517-26.

31. Garg AD, Dudek AM, Agostinis P. Autophagy-dependent suppression of cancer immunogenicity and effector mechanisms of innate and adaptive immunity. Oncoimmunology. 2013;2(10):e26260.

32. Tan SH, Shui G, Zhou J, Li JJ, Bay BH, Wenk MR, Shen HM. Induction of autophagy by palmitic acid via protein kinase C-mediated signaling pathway independent of mTOR (mammalian target of rapamycin). J Biol Chem. 2012:287(18):14364-76.

33. Chen JL, Lin HH, Kim KJ, Lin A, Ou JH, Ann DK. PKC signaling. A dual role in regulating hypoxic stress-induced autophagy and apoptosis. Autophagy. 2009;5:244-6.

34. Rosivatz E, Woscholski R. Removal or masking of phosphatidylinositol(4,5)bisphosphate from the outer mitochondrial membrane causes mitochondrial fragmentation. Cell Signal. 2011;23:478-86.

35. Silva RD, Manon S, Goncalves J, Saraiva L, Corte-Real M. Modulation of Bax mitochondrial insertion and induced cell death in yeast by mammalian protein kinase Calpha. Exp Cell Res. 2011;317:781-90.

36. Sridharan S, Jain K, Basu A. Regulation of autophagy by kinases. Cancer. 2011;3:2630-54

37. Maher EA, Furnari FB, Bachoo RM, Rowitch DH, Louis DN, Cavenee WK, RA DP. Malignant glioma: genetics and biology of a grave matter. Genes Dev. 2001;15:1311-33.

38. Hoelzinger DB, Mariani L, Weis J, Woyke T, Berens TJ, McDonough WS, Sloan A, Coons SW, Berens ME. Gene expression profile of glioblastoma Multiforme invasive phenotype points to new therapeutic targets. Neoplasia. 2005;7(1):7-16.

39. Mizushima N, Yamamoto A, Hatano M, Kobayashi Y, Kabeya Y, Suzuki K, Tokuhisa T, Ohsumi Y, Yoshimori T. Dissection of autophagosome formation using Apg5-deficient mouse embryonic stem cells. J Cell Biol. 2001;152(4): 657-68. 
40. Jiang $X$, Overholtzer $M$, Thompson CB. Autophagy in cellular metabolism and cancer. J Clin Invest. 2015;125(1):47-54.

41. Dai ZJ, Gao J, Kang HF, Ma YG, Ma XB, Lu WF, Lin S, Ma HB, Wang XJ, Wu WY. Targeted inhibition of mammalian target of rapamycin (mTOR) enhances radiosensitivity in pancreatic carcinoma cells. Drug Des Devel Ther. 2013;7:149-59.

42. Maskey D, Yousefi S, Schmid I, Zlobec I, Perren A, Friss R, Simon HU. ATG5 is induced by DNA-damaging agents and promotes mitotic catastrophe independent of autophagy. Nat Commun. 2013;4:2130.

43. Toton E, Lisiak N, Sawicka P, Rybczynska M. Beclin-1 and its role as a target for anticancer therapy. J Physiol Pharmacol. 2014;65(4):459-67.

44. Mizushima N, Yoshimori T, Levine B. Method in mammalian autophagy research. Cell. 2010;140:313-26.

45. Gong C, Bauvy C, Tonelli G, Yue W, Deloménie C, Nicolas V, Zhu Y, Domergue V, Marin-Esteban V, Tharinger H, Delbos L, Gary-Gouy H, Morel AP, Ghavami S, Song E, Codogno P, Mehrpour M. Beclin 1 and autophagy are required for the tumorigenicity of breast cancer stem-like/progenitor cells. Oncogene. 2013;32:2261-72.

46. Hasima N, Ozpolat B. Regulation of autophagy by polyphenolic compounds as a potential therapeutic strategy for cancer. Cell Death Dis. 2014;5 https:// doi.org/10.1038/cddis.2014.467.

47. Yang ZJ, Chee CE, Huang S, Sinicrope FA. The role of autophagy in cancer: therapeutic implications. Mol Cancer Ther. 2011;10:1533-41.

48. Klionsky DJ, Abdelmohsen K, Abe A, Abedin MJ, Abeliovich H, Acevedo Arozena A, Adachi H, Adams CM, Adams PD, et al. Guidelines for the use and interpretation of assays for monitoring autophagy (3rd edition). Autophagy. 2016;12(1):1-222.

49. Marquez RT, Xu L. Bcl-2:Beclin 1 complex: multiple, mechanisms regulating autophagy/apoptosis toggle switch. Am J Cancer Res. 2012;2:214-21.

50. Fassina L, Magenes G, Inzaghi A, Palumbo S, Allavena G, Miracco C, Pirtoli L, Biggiogera M, Comincini S. AUTOCOUNTER, an ImageJ JavaScript to analyze LC3B-GFP expression dynamics in autophagy-induced astrocytoma cells. Eur J Histochem. 2012;56(4):e44.

51. Lawson CD, Burridge K. The on-off relationship of rho and Rac during integrin-mediated adhesion and cell migration. Small GTPases. 2014;5: e27958. https://doi.org/10.4161/sgtp.27958.

52. Lisiak N, Paszel-Jaworska A, Totoń E, Rubiś B, Pakuła M, Bednarczyk-Cwynar B, Zaprutko L, Rybczyńska M. Semisynthetic oleanane triterpenoids inhibit migration and invasion of human breast cancer cells through downregulated expression of the ITGB1/PTK2/PXN pathway. Chem Biol Interact. 2017;268:136-47.

53. Schaller MD. Cellular functions of FAK kinases: insight into molecular mechanisms and novel functions. J Cell Sci. 2010;123:1007-13.

54. Heidkamp MC, Bayer AL, Scully BT, Eble DM, Samarel AM. Activation of focal adhesion kinase by protein kinase $C$ epsilon in neonatal rat ventricular myocytes. Am J Physiol Heart Circ Physiol. 2003;285(4):H1684-96.

55. Zeidman R, Trollér U, Raghunath A, Påhlman S, Larsson C. Protein kinase C epsilon actin-binding site is important for neurite outgrowth during neuronal differentiation. Mol Biol Cell. 2002;13(1):12-24.

56. Zhou S, Zhao L, Kuang M, Zhang B, Liang Z, Yi T, Wei Y, Zhao X. Autophagy in tumorigenesis and cancer therapy: Dr. Jekyll or Mr. Hyde. Cancer Lett. 2012;323:115-27

57. Huang X, Qi Q, Hua X, Li X, Zhang W, Sun H, Li S, Wang X, Li B. Beclin1, an autophagy-related gene, augments apoptosis in U87 glioblastoma cells. Oncol Rep. 2014;31(4):1761-7. https://doi.org/10.3892/or.2014.3015.

58. Wang S, Li X, Wang Q, Xiu Z. Autophagy inhibitor sensitizes MCF-7 breast cancer cells to novel cyclic tetrapeptide CTS203-induced caspase-9dependent apoptotic cell death. Neoplasma. 2015;62(2):220-9. https://doi. org/10.4149/neo_2015_027.

59. Lebovitz CB, Robertson AG, Goya R, Jones SJ, Morin RD, Marra MA, Gorski SM. Cross-cancer profiling of molecular alterations within the human autophagy interaction network. Autophagy 2015:0. [Epub ahead of print].

60. Winardi D, Tsai H-P, Chai C-Y, Chung CL, Loh JK, Chen YH, Hsieh CL. Correlation of alered expression of the autophagy marker LC3B with poor prognosis in astrocytoma. Biomed Res Int. 2014;2014:723176. https://doi.org/ $10.1155 / 2014 / 723176$

61. Yu Y, Yu X, Ma J, Tong Y, Yao J. Effects of NVP-BEZ235 on the proliferation, migration, apoptosis and autophagy in HT-29 human colorectal adenocarcinoma cells. Int J Oncol. 2016;49(1):285-93.
62. Peltier J, O'Neill A, Schaffer DV. PI3K/Akt and CREB regulate adult neural hippocampal progenitor proliferation and differentiation. Dev Neurobiol. 2007;67:1348-61.

63. Yang F, Gao JY, Chen H, Du ZH ZXQ, Gao W. Targeted inhibition of the phosphoinositide 3-kinase impairs cell proliferation, survival, and invasion in colon cancer. Onco Targets Ther. 2017;10:4413-22.

64. Tai YL, Chen LC, Shen TL. Emerging roles of focal adhesion kinase in cancer. Biomed Res Int. 2015:690690.

65. Yoon H, Dehart JP, Murphy JM, Lim ST. Understanding the roles of FAK in cancer: inhibitors, genetic models, and new insights. J Histochem Cytochem. 2015;63(2):114-28.

66. Jaraíz-Rodríguez M, Tabernero MD, González-Tablas M, Otero A, Orfao A, Medina JM, Tabernero A. A short region of connexin43 reduces human glioma stem cell migration, invasion, and survival through Src, PTEN, and FAK. Stem Cell Reports. 2017;9(2):451-63.

67. Nam JH, Cho HJ, Kang H, Lee JY, Jung M, Chang YC, Kim K, Hoe HS. A mercaptoacetamide-based class II histone deacetylase inhibitor suppresses cell migration and invasion in monomorphic malignant muman glioma cells by inhibiting FAK/STAT3 signaling. J Cell Biochem. 2017;118(12):4672-85.

68. Khotskaya YB, Beck BH, Hurst DR, Han Z, Xia W, Hung MC, Welch DR. Expression of metastasis suppressor BRMS1 in breast cancer cells results in a marked delay in cellular adhesion to matrix. Mol Carcinog. 2014; 53(12):1011-26.

69. De Witt Hamer PC, Van Tilborg AA, Eijk PP, Sminia P, Troost D, Van Noorden CJ, Ylstra B, Leenstra $\mathrm{S}$. The genomic profile of human malignant glioma is altered early in primary cell culture and preserved in spheroids. Oncogene. 2008;27(14):2091-6.

70. Robert G, Ben Sahra I, Puissant A, Colosetti P, Belhacene N, Gounon P, Hofman P, Bost F, Cassuto JP, Auberger P. Acadesine kills chronic myelogenous leukemia (CML) cells through PKC-dependent induction of autophagic cell death. PLoS One. 2009;4:e7889.

71. Hu YL, Jahangiri A, Delay M, Aghi MK. Tumor cell autophagy as an adaptive response mediating resistance to treatments such as antiangiogenic therapy. Cancer Res. 2012;72:4294-9.

\section{Submit your next manuscript to BioMed Central and we will help you at every step:}

- We accept pre-submission inquiries

- Our selector tool helps you to find the most relevant journal

- We provide round the clock customer support

- Convenient online submission

- Thorough peer review

- Inclusion in PubMed and all major indexing services

- Maximum visibility for your research

Submit your manuscript at www.biomedcentral.com/submit 